\title{
1 cAMP prevents antibody-mediated thrombus formation in COVID-19
}

2

\author{
Jan Zlamal ${ }^{1 *}$, Karina Althaus ${ }^{1,2^{\star}}$, Hisham Jaffal ${ }^{1}$, Lisann Pelzl ${ }^{1}$, Anurag Singh $^{1}$, Andreas
}

Witzemann ${ }^{1}$, Helene Häberle ${ }^{3}$, Valbona Mirakaj ${ }^{3}$, Peter Rosenberger ${ }^{3}$ and Tamam $^{2}$

Bakchoul $^{1,2}$

${ }^{1}$ Institute for Clinical and Experimental Transfusion Medicine, Medical Faculty of Tuebingen, University Hospital of Tuebingen

${ }^{2}$ Centre for Clinical Transfusion Medicine, University Hospital of Tuebingen

${ }^{3}$ Department of Anesthesiology and Intensive Care Medicine, University Hospital of

Tuebingen

* Indicates equal contribution

Running title: cAMP prevents antibody-induced procoagulant platelets

Tables: 1

Figures: 10

Key words: procoagulant platelet, Fc-gamma-receptor IIA, COVID-19, cAMP

\section{Corresponding author:}

Tamam Bakchoul, MD

University Hospital of Tuebingen

Otfried-Müller-Straße 4/1

72076 Tübingen

Tel: +49-(0)7071 / 29-81601, Fax: +49-(0)7071 / 29-5240

E-mail: tamam.bakchoul@med.uni-tuebingen.de

NOTE: This preprint reports new research that has not been certified by peer review and should not be used to guide clinical practice. 
medRxiv preprint doi: https://doi.org/10.1101/2020.12.15.20247775; this version posted December 17, 2020. The copyright holder for this preprint (which was not certified by peer review) is the author/funder, who has granted medRxiv a license to display the preprint in All rights reserved. No reuse allowed without permission.

\section{Key points}

31 - Fc-gamma-receptor IIA mediated PS externalization on the PLT surface triggers increased thrombus formation

- Inductors of CAMP inhibit antibody-mediated thrombus formation and may 
medRxiv preprint doi: https://doi.org/10.1101/2020.12.15.20247775; this version posted December 17, 2020. The copyright holder for this preprint (which was not certified by peer review) is the author/funder, who has granted medRxiv a license to display the preprint in

All rights reserved. No reuse allowed without permission.

\section{Abstract}

37 Thromboembolic events are frequently reported in patients infected with the SARS-

38 CoV-2 virus. However, the exact mechanisms of thromboembolic events remain

39 elusive. In this work, we show that immunoglobulin $\mathrm{G}(\lg G)$ subclass in patients with

40 COVID-19 trigger the formation of procoagulant PLTs in a Fc-gamma-RIIA (FcyRIIA)

41 dependent pathway leading to increased thrombus formation in vitro. Most

42 importantly, these events were significantly inhibited via FcyRIIA blockade as well as

43 by the elevation of PLTs' intracellular cyclic-adenosine-monophosphate (CAMP)

44 levels by the clinical used agent lloprost. The novel findings of FcyRIIA mediated

45 prothrombotic conditions in terms of procoagulant PLTs leading to higher thrombus

46 formation as well as the successful inhibition of these events via lloprost could be

47 promising for the future treatment of the complex coagulopathy observed in COVID-

4819 disease. 
medRxiv preprint doi: https://doi.org/10.1101/2020.12.15.20247775; this version posted December 17, 2020. The copyright holder for this preprint (which was not certified by peer review) is the author/funder, who has granted medRxiv a license to display the preprint in

All rights reserved. No reuse allowed without permission.

50

51

\section{Introduction}

Infection with SARS-CoV-2 has been shown to be associated with abnormalities in the coagulation system with an increased incidence of thromboembolic events in small vessels leading to higher mortality (1-3). Accumulating evidence suggests upregulated release of inflammatory cytokines and increased interaction between different actors of innate and adaptive immunity as the main causes for the prothrombotic environment observed in COVID-19 disease (4). Moreover, a significant number of reports described platelet (PLT) hyperactivity in patients with COVID-19, which is assumed to contribute to prothrombotic conditions $(5,6)$. Procoagulant PLTs, predominantly generated at the outer side of the growing thrombus, are increasingly recognized to link primary with secondary haemostasis (710). The latter is mainly executed by negatively charged membrane phospholipids externalized on the PLT surface. This unique feature of procoagulant PLTs enables the assembly of tenase as well as prothrombinase complexes leading to high thrombin burst, increased fibrin deposition and thrombus formation (11). Recently, we showed that PLTs from patients with severe COVID-19 infection express a procoagulant phenotype. Immunoglobulin $G(\lg G)$ fractions were found to be responsible for the COVID-19 induced procoagulant PLTS (Althaus et al. accepted). In the current study, we investigate the time course of the generation of antibody- induced procoagulant PLTs as well as the mechanisms leading to alterations in the PLT phenotype in COVID-19. We observed that IgG fractions from severe COVID-19 patients induce increased thrombus formation in an Fc-gamma RIIA (FcyRIIA) dependent manner. More importantly, we were able to show that cyclic-adenosine-monophosphate (cAMP) elevation in PLTs prevents COVID-19 antibody-induced procoagulant PLT generation as well as clot formation. 
medRxiv preprint doi: https://doi.org/10.1101/2020.12.15.20247775; this version posted December 17 , 2020. The copyright holder for this preprint (which was not certified by peer review) is the author/funder, who has granted medRxiv a license to display the preprint in

All rights reserved. No reuse allowed without permission.

\section{Materials and Methods}

\section{Patients and sera}

Experiments were performed using leftover serum material from COVID-19 patients who were referred to our laboratory between March and June 2020. The diagnosis of SARS-CoV-2 infection was confirmed by real time PCR on material collected by nasal swabs. Sera from ICU non-Covid-19 patients with postoperative sepsis were collected to serve as ICU control group. Additionally, sera were collected from healthy blood donors at the Blood Donation Centre Tuebingen after written consensus was obtained to establish cutoff values when appropriate. Serum samples were stored at $-80^{\circ} \mathrm{C}$ and thawed at room temperature prior to the performed experimental procedure. All sera were heat-inactivated at $56^{\circ} \mathrm{C}$ for 30 minutes (min), which was followed by a centrifugation step at $5000 \mathrm{xg}$. The spun-down was discarded and supernatants were handled as described in the following sections.

\section{IgG preparation}

IgG fractions were isolated by the use of a commercially available IgG-purification-kit (Melon ${ }^{\mathrm{TM}}$-Gel IgG Spin Purification Kit, Thermo Fisher Scientific, Waltham, USA) and used as recommended by the manufacturer. In brief, heat inactivated serum was diluted 1:10 in purification buffer and incubated with the kit specific Gel IgG Purification Support over four cycles for $10 \mathrm{~min}$. Subsequently, periodically performed centrifugation steps through a $10 \mu \mathrm{m}$ pore size filter tube were performed for $1 \mathrm{~min}$ at 5000xg. The flow throw was collected into $100 \mathrm{kDa}$-pore sized centrifugal filters (Amicon Ultra-4, Merck Millipore, Cork, Ireland) with subsequent concentration to the initial volume of the used serum sample via centrifugation $\left(10-15 \mathrm{~min}, 2000 \mathrm{xg}, 4^{\circ} \mathrm{C}\right.$, with brake). Afterwards, IgG concentrations were measured at a mass extinction 
medRxiv preprint doi: https://doi.org/10.1101/2020.12.15.20247775; this version posted December 17, 2020. The copyright holder for this preprint (which was not certified by peer review) is the author/funder, who has granted medRxiv a license to display the preprint in

All rights reserved. No reuse allowed without permission.

99

100

101

102

103

104

105

106

107

108

109

110

111

112

113

114

115

116

117

118

119

120

121

122

coefficient of 13.7 at $280 \mathrm{~nm}$ wavelength using a NanoDrop One spectrophotometer (VWR, Bruchsal, Germany). IgG purity was verified using Coomassie staining (Abcam, Cambridge, UK).

\section{Preparation of washed platelets}

Washed platelets (wPLTs) were prepared from venous blood samples as described previously (12). Briefly, whole blood from healthy donors was withdrawn by cubital venipuncture into acidic-dextrose containing vacutainers (Becton-Dickinson, Plymouth, UK) and allowed to rest for $45 \mathrm{~min}$ at $37^{\circ} \mathrm{C}$. After centrifugation (20 min, 120xg, room temperature $[R T]$, no brake) PLT-rich-plasma (PRP) was gently separated and supplemented with apyrase ( $5 \mu \mathrm{L} / \mathrm{mL}$, Sigma-Aldrich, St. Louis, USA) and prewarmed ACD-A (111 $\mu \mathrm{L} / \mathrm{mL}$, Terumo BCT, Inc., Lakewood, USA). After an additional centrifugation step (7 min, 650xg, RT, no brake), the PLT pellet was resuspended in $5 \mathrm{~mL}$ of wash-solution (modified Tyrode buffer: $5 \mathrm{~mL}$ bicarbonate buffer, 20 percent (\%) bovine serum albumin, 10\% glucose solution [Braun, Melsungen, Germany], $2.5 \mathrm{U} / \mathrm{mL}$ apyrase, $1 \mathrm{U} / \mathrm{mL}$ hirudin [Pentapharm, Basel, Swiss], $\mathrm{pH}$ 6.3) and allowed to rest for $15 \mathrm{~min}$ at $37^{\circ} \mathrm{C}$. Following final centrifugation (7 min, 650xg, RT, no brake) wPLTs were resuspended in $2 \mathrm{~mL}$ of resuspensionbuffer ( $50 \mathrm{~mL}$ of modified Tyrode buffer, $0.5 \mathrm{~mL}$ of $0.1 \mathrm{M} \mathrm{MgCl} 2,1 \mathrm{~mL}$ of $0.2 \mathrm{M}$ $\mathrm{CaCl} 2, \mathrm{pH}$ 7.2) and adjusted to $300 \times 10^{9} \mathrm{PLTs} / \mathrm{L}$ after the measurement at a Cell-Dyn Ruby hematological analyzer (Abott, Wiesbaden, Germany) was performed. For calcium chelation experiments, the PLT pellet was resuspended with resuspensionbuffer without the supplementation of calcium $(50 \mathrm{~mL}$ of modified Tyrode buffer, 0.5 $\mathrm{mL}$ of $0.1 \mathrm{M} \mathrm{MgCl} 2, \mathrm{pH} 7.2)$.

\section{Treatment of wPLTs with ICU COVID-19 sera/IgG}


medRxiv preprint doi: https://doi.org/10.1101/2020.12.15.20247775; this version posted December 17, 2020. The copyright holder for this preprint (which was not certified by peer review) is the author/funder, who has granted medRxiv a license to display the preprint in

All rights reserved. No reuse allowed without permission.

123 wPLTs $\left(7.5 \times 10^{6}\right)$ were supplemented with $5 \mu \mathrm{L}$ serum/lgG from ICU COVID-19

124 patients or control serum/lgG and incubated for 1.5 hours (hs) at RT under rotating

125 conditions. Afterwards, samples were washed once (7 min, 650xg, RT, no brake),

126 resuspended in $100 \mu \mathrm{L}$ of phosphate buffered saline (PBS, [Biochrom, Berlin,

127 Germany]) and further handled as described in the following sections.

128 Detection of phosphatidylserine exposure

129 To assess externalization of phosphatidylserine (PS) on the PLT surface after

130 antibody treatment, $10 \mu \mathrm{L}$ of PLT suspension were transferred into $100 \mu \mathrm{L}$ of Hank's

131 balanced salt solution (HBSS), (137 mM NaCl, $1.25 \mathrm{mM} \mathrm{CaCl}_{2}, 5.5 \mathrm{mM}$ glucose,

132 [Carl-Roth, Karlsruhe, Germany]) and incubated with $1 \mu \mathrm{L}$ Annexin V-FITC

133 (Immunotools, Friesoythe, Germany) for $30 \mathrm{~min}$ at RT in the dark. To induce the

134 maximal externalization of PS on the PLT surface, wPLTs were incubated with

135 ionomycin (Sigma-Aldrich, St. Louis, USA, [5 $\mu \mathrm{M}, 15$ min at RT]). Afterwards, PLTs

136 were filled up with HBSS to a final volume of $500 \mu \mathrm{L}$ and acquired at a flow cytometer

137 ([FC], Navios, Beckman-Coulter, Brea, USA).

138 PLTs were gated based on their characteristic forward scatter (FSC) vs. side

139 scatter (SSC) properties as well as CD41a and CD42a expression (anti-CD41a-PC5

140 and anti-CD42a-PerCP, both BD, San Jose, USA), respectively. Test results were

141 analyzed as fold increase of the percentage PS positive PLTs compared to PLTs that

142 were incubated with serum/lgG from healthy individuals.

143 Determination of changes in the inner-mitochondrial-transmembrane potential

$144(\Delta \Psi)$

145 Changes of the mitochondrial inner transmembrane potential $(\Delta \Psi)$ induced by ICU

146 COVID-19 sera/lgG were analyzed by FC, as previously reported (13). Briefly, after 
medRxiv preprint doi: https://doi.org/10.1101/2020.12.15.20247775; this version posted December 17, 2020. The copyright holder for this preprint (which was not certified by peer review) is the author/funder, who has granted medRxiv a license to display the preprint in

All rights reserved. No reuse allowed without permission.

147 treatment with IgG/serum from ICU COVID-19 patients, wPLTs $\left(\sim 2 \times 10^{6}\right)$ were

148 incubated with a final concentration of $10 \mu \mathrm{M}$ tetramethylrhodamine, ethyl ester

149 (TMRE, Abcam, Cambridge, UK) for 30 min at RT in the dark. Carbonyl cyanide 4-

150 (trifluoromethoxy) phenylhydrazone (FCCP, Abcam, Cambridge, UK) which is an

151 uncoupler of mitochondrial oxidative phosphorylation served as positive control in

152 each experiment. After staining with TMRE, PLTs were filled up with PBS to a final

153 volume of $500 \mu \mathrm{L}$ and immediately analyzed by FC. Changes in the $\Delta \Psi$ were

154 determined in gated PLTs as percentage of TMRE negative events and normalized to

155 PLTs that were treated with serum/lgG from healthy controls.

\section{Phenotyping of different PLT-populations}

157 ICU COVID-19 serum/lgG-mediated procoagulant changes (PS/CD62p-double

158 positive) were assessed in some experiments using a triple staining. Briefly, $10 \mu \mathrm{L}$

$159\left(\sim 1 \times 10^{6}\right)$ of the resuspended PLT suspension were transferred into $10 \mu \mathrm{L}$ of HBSS

160 and incubated with $1 \mu \mathrm{L}$ anti-CD62p-APC (BD, San Jose, USA), $1 \mu \mathrm{L}$ Annexin-FITC

161 (Immunotools, Friesoythe, Germany) and $1 \mu \mathrm{L}$ anti-CD42a-PerCP (BD, San Jose,

162 USA) for 15 min at RT in the dark. PLTs treated with thrombin receptor activating

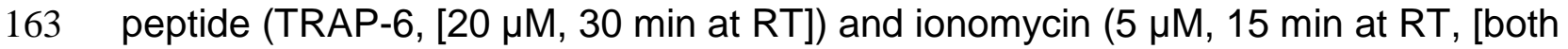

164 Sigma-Aldrich, St. Louis, USA]) served as positive controls. Afterwards, PLTs were

165 resuspended with HBSS to a final volume of $500 \mu \mathrm{L}$ and immediately assessed via

166 FC. In selected experiments that were designed to investigate the impact of calcium

167 on cell signalling, PLT PS externalization was assessed by the use of the calcium

168 independent marker lactadherin. $1 \mu \mathrm{L}$ of lactadherin-FITC (Haematologic

169 Technologies, Essex Junction, USA) was incubated with wPLTs as for Annexin-FITC

170 for 15 min at RT, in the dark, and the PLT suspension filled up to final volume of 500

$171 \mu \mathrm{L}$ with PBS prior to $\mathrm{FC}$ analysis. 
medRxiv preprint doi: https://doi.org/10.1101/2020.12.15.20247775; this version posted December 17, 2020. The copyright holder for this preprint (which was not certified by peer review) is the author/funder, who has granted medRxiv a license to display the preprint in

All rights reserved. No reuse allowed without permission.

\section{Western blot analysis of caspase 3 cleavage}

173 Protein levels of cleaved-caspase 3 were determined by western blot. After

174 serum/lgG incubation, cells were washed with PBS for $7 \mathrm{~min}, 700 \times \mathrm{xg}$ at $4^{\circ} \mathrm{C}$.

175 Subsequently, the pellet was resuspended in $100 \mu \mathrm{L}$ of ice-cold RIPA lysis buffer

176 containing $\mathrm{HALT}^{\mathrm{TM}}$ protease and phosphatase inhibitor-cocktail (both ThermoFisher

177 Scientific, Paisley, UK). Protein concentrations were determined using the NanoDrop

178 One spectrophotometer (VWR, Bruchsal, Germany). $100 \mu \mathrm{g}$ of protein was

179 solubilized in sample buffer (Invitrogen ${ }^{\mathrm{TM}}$, Carlsbad, USA) at $95^{\circ} \mathrm{C}$ for $10 \mathrm{~min}$.

180 Proteins were separated by electrophoresis using 12\% SDS-PAGE gels in glycine-

181 tris buffer. Thereafter, probes were transferred to polyvinylidene difluoride (PVDF)

182 membranes (0.45 $\mu \mathrm{m}$, Merck, Tullagreen, Ireland). Afterwards, membranes were

183 blocked with 5\% milk in tris-buffered saline (TBS-T, $20 \mathrm{mM}$ Tris, $140 \mathrm{mM} \mathrm{NaCl}, 0.1 \%$

184 Tween, $\mathrm{pH}$ 7.6) at RT for $1 \mathrm{~h}$. Membranes were then incubated with primary anti-

185 human cleaved-caspase 3 antibody (1:1000, Abcam, Cambridge, UK) and anti-

186 human alpha-tubulin (1:1000, Cell Signaling Technology, Danvers, USA) at $4^{\circ} \mathrm{C}$

187 overnight. After washing with TBS-T buffer, the membranes were incubated with the

188 appropriate secondary anti-rabbit or anti-mouse antibody conjugated with IRDye ${ }^{\circledR} 680$

189 / IRDye ${ }^{\circledR} 800$ (1:3000, LI-COR ${ }^{\circledR}$, Lincoln, USA) for $1 \mathrm{~h}$ at RT. Protein bands were

190 detected after additional washes (TBS-T) with Odyssey infrared imaging system (LI-

$191 \mathrm{COR}^{\circledR}$, Lincoln, USA). Western blots were analyzed by ImageJ software (NIH,

192 Bethesda, USA). The results are shown as the ratio of total cleaved-caspase 3 to

193 procaspase 3 (full fragment) and normalized to wPLTs that were treated with healthy

194 control serum/lgG.

195 Assessment of the mechanisms of antibody-mediated effects on PLTs 
medRxiv preprint doi: https://doi.org/10.1101/2020.12.15.20247775; this version posted December 17, 2020. The copyright holder for this preprint (which was not certified by peer review) is the author/funder, who has granted medRxiv a license to display the preprint in All rights reserved. No perpetuity.

$19675 \mu \mathrm{L}$ wPLTs were pretreated with the FcyRIIA blocking monoclonal antibody (moAb) anti-CD32 (5 $\mu \mathrm{L}$ moAb IV.3; stemcell ${ }^{\mathrm{TM}}$ technologies, Vancouver, Canada) for 45 min at $37^{\circ} \mathrm{C}$ prior to serum/lgG treatment. A monoclonal isotype (moAb) served as vehicle control ([SC-2025], Santa Cruz Biotechnology, Dallas, USA). used.

For the depletion of calcium in the inner compartment of PLTs, the intracellular chelator of calcium BAPTA-AM (1,2-Bis(2-aminophenoxy)ethane-N,N,N',N'tetraacetic acid tetrakis(acetoxymethyl) ester, $20 \mu \mathrm{M}, 15 \mathrm{~min}$ at $37^{\circ} \mathrm{C}$, [Selleck, 207 Houston, USA]) was used.

To investigate the effect of increased intracellular levels of cAMP, wPLTs were pretreated with the adenylate cyclase (ADC) inducers Forskolin $(2.25 \mu \mathrm{M})$ and Iloprost (20 nM, both Sigma-Aldrich, St. Louis, USA) prior to the incubation with sera/IgGs from ICU COVID-19 patients.

\section{Investigations of antibody-mediated thrombus formation}

To assess the impact of ICU COVID-19 IgG-induced effects on clot formation, an ex

214 vivo model for thrombus formation was established. A microfluidic system (BioFlux, 215 Fluxion Biosciences, Alameda, USA) was used at a shear rate of $1500^{-1}$ (60 dyne) 216 according to the recommendations of the ISTH standardization committee for 217 biorheology (14). Briefly, microfluidic channels were coated with collagen (100 $218 \mu \mathrm{g} / \mathrm{mL}$, Collagen Horm, Takeda, Linz, Austria) overnight at $4^{\circ} \mathrm{C}$ and blocked with 
medRxiv preprint doi: https://doi.org/10.1101/2020.12.15.20247775; this version posted December 17, 2020. The copyright holder for this preprint (which was not certified by peer review) is the author/funder, who has granted medRxiv a license to display the preprint in

All rights reserved. No reuse allowed without permission.

$2192.5 \%$ of human serum albumin (HSA, Kedrion, Barga, Italy) $1 \mathrm{~h}$ before perfusion at

220 RT.

221 Whole blood samples of healthy individuals of blood group O were collected into

222 hirudin containing monovettes (Sarstedt, Nuembrecht, Germany) and allowed to rest

223 for 30 min at RT. After splitting the whole blood into aliquots of $200 \mu \mathrm{L}$, PRP was

224 prepared via centrifugation (20 min, 120xg, at RT, no break). Afterwards, $45 \mu \mathrm{L}$ of the

225 supernatant PRP was gently separated and incubated with $5 \mu \mathrm{L}$ of control or ICU

226 COVID-19 IgG fractions and incubated for 90 min at RT under rotating conditions. 15

227 min prior to the end of the incubation period, Calcein-FITC (4 $\mu \mathrm{M}$, [Thermo Scientific,

228 Eugene, Oregon, USA]) was added to each sample. Subsequently, PRP was gently

229 added back to reconstitute whole blood samples.

When indicated, the separated PRP was pretreated with moAb IV.3 or moAb

231 isotype control at a concentration of $20 \mu \mathrm{g} / \mathrm{mL}$ for $30 \mathrm{~min}$ at RT. For cAMP induction,

232 PRP was pretreated with lloprost $(20 \mathrm{nM})$ or vehicle control $\left(5 \mathrm{~min}, 37^{\circ} \mathrm{C}\right)$ prior to $\operatorname{lgG}$

233 incubation.

234 Finally, reconstituted whole blood samples were run at a shear rate of $1500 s^{-1}$

235 (60 dyne) for a maximum of $5 \mathrm{~min}$. Immunofluorescence and bright field images were

236 taken from 3-5 randomly chosen microscopic fields (x20, Olympus IX73, Olympus

$237 \mathrm{GmbH}$, Hamburg, Germany). Clot formation was assessed by measuring the \% of

238 surface area coated by thrombus (SAC) of 3-5 images via ImageJ (NIH, Bethesda,

239 USA) and normalized to the whole area.

240 Statistical analysis

241 Statistical analyses were performed using GraphPad Prism 7 (La Jolla, USA). T-test

242 was used to analyze normally distributed results. Non-parametric test (Mann-Whitney

243 test) was used when data failed to follow a normal distribution as assessed by 
medRxiv preprint doi: https://doi.org/10.1101/2020.12.15.20247775; this version posted December $17,2020$. The copyright holder for this preprint (which was not certified by peer review) is the author/funder, who has granted medRxiv a license to display the preprint in All rights reserved. No reuse allowed without permission.

244 D'Agostino and Pearson omnibus normality test. Group comparison was performed 245 using the Wilcoxon rank-sum test and the Fisher exact test with categorical variables.

246 A p-value $<0.05$ was assumed to represent statistical significance.

\section{Ethics}

248 Studies involving human material were approved by the Ethics Committee of the

249 Medical Faculty, Eberhard-Karls University of Tuebingen, Germany, and were

250 conducted in accordance with the declaration of Helsinki. 
medRxiv preprint doi: https://doi.org/10.1101/2020.12.15.20247775; this version posted December 17, 2020. The copyright holder for this preprint (which was not certified by peer review) is the author/funder, who has granted medRxiv a license to display the preprint in

All rights reserved. No reuse allowed without permission.

251

252

253

254

255

256

257

258

259

260

261

262

263

264

265

266

\section{Results}

\section{Patient characteristics}

Sera from 26 ICU COVID-19 patients were enrolled in this study between March the $1^{\text {st }}$ and June the $16^{\text {th }} 2020.21$ of these ICU COVID-19 patients were included in a previous study (Althaus et al. accepted). The mean age of ICU COVID-19 patients was 58 years (range: 29-88 years). 20/30 (67\%) patients had known risk factors for severe COVID-19 infection as described previously (15), including hypertension $18 / 30(60 \%)$, obesity $6 / 30(20 \%)$, coronary artery disease $4 / 30(13 \%)$ and diabetes mellitus 6/30 (20\%). Elevated D-Dimer levels were detected in all patients (median, range: $3.4 \mathrm{mg} / \mathrm{dL}, 0.9-45.0 \mathrm{mg} / \mathrm{dL}$ ) and thrombosis was diagnosed in 13/30 (43\%) patients. Longitudinal blood samples were available from four COVID-19 patients who were first admitted to normal ward and later to the ICU for mechanical ventilation. As ICU control group, 5 patients who were admitted to ICU due to nonCOVID-19 related causes were included in this study.

Sera from ICU COVID-19 patients induce progressive increase of procoagulant PLTS

To investigate whether sera of ICU COVID-19 patients have the potential to induce an increased $\Delta \Psi$ depolarization as well as PS externalization on the PLT surface, wPLTs from healthy individuals were incubated with sera from 26 ICU COVID-19 patients with a severe course of disease as well as 5 ICU non-COVID-19 patients. Based on the calculated cuttoffs (mean+2xSD of healthy controls), 19/26 (73\%) sera from patients with severe COVID-19 disease induced significantly higher $\Delta \Psi$ depolarization in PLTs from healthy donors compared to ICU controls (FI in $\% \Delta \psi$ depolarization \pm SEM: $6.10 \pm 1.12$ vs. $0.67 \pm 0.10$, p value $<0.0001$, Fig. 1 A). In addition, 
medRxiv preprint doi: https://doi.org/10.1101/2020.12.15.20247775; this version posted December 17, 2020. The copyright holder for this preprint (which was not certified by peer review) is the author/funder, who has granted medRxiv a license to display the preprint in

All rights reserved. No reuse allowed without permission.

275 significantly higher PS externalization was observed when ICU COVID-19 sera were

276 incubated with PLTs compared to ICU control sera (FI in \% PS \pm SEM: $2.12 \pm 0.19$ vs.

$277 \quad 1.12 \pm 0.08$, p value $<0.0001$, Fig. 1 B)

278 Next, we sought to investigate the time course of the observed changes in

279 both markers. Longitudinal blood samples were available from four ICU COVID-19

280 patients. Sera were collected at hospital admission (normal ward or ICU) and during

281 a follow up period at ICU for up to 14 days. As shown in Fig. 1 C-F, sera from ICU

282 COVID-19 patients induced significant changes in $\Delta \psi$ depolarization, PS

283 externalization and caspase 3 cleavage as clinical manifestation worsen requiring

284 admission to ICU. Of note, antibody-induced changes peaked within day 3 and 7 of

285 the ICU stay (FI in $\% \Delta \psi$ depolarization \pm SEM: $3.71 \pm 0.72, p$ value $0.0070 ;$ and $\%$ PS

286 externalization \pm SEM: 4.80 \pm 1.11 , p value $<0.0001$, respectively, Suppl. Fig. 1).

287 These findings were further supported by WB analyses, as PLTs incubated with the

288 corresponding ICU COVID-19 serum induced caspase 3 cleavage in similar kinetic

289 (Ratio of cleaved caspase 3/procaspase 3 normalized to control \pm SEM: $4.84 \pm 0.45, p$

290 value 0.0035, Fig. $1 \mathrm{E}+\mathrm{F})$. Notably, the rise of PLT markers was associated with

291 increasing levels of detected IgGs against the spike S protein of SARS-CoV-2 in the

292 corresponding ICU COVID-19 patients' follow up sera but not in the total IgG

293 contents of isolated IgG fractions (Suppl. Fig. 2 A and B, respectively). Moreover,

294 declining PLT-counts were observed as $\Delta \psi$ depolarization as well as PS

295 externalization increased, vice versa (Suppl. Fig. 3 A and B, respectively).

296 IgGs from severe COVID-19 trigger procoagulant PLTs with increased ability to

297 form blood clots

298 To further verify the impact of sera from severe COVID-19 patients on PLTs, the

299 expression of the alpha granule release and PLT activation marker CD62p was 
medRxiv preprint doi: https://doi.org/10.1101/2020.12.15.20247775; this version posted December 17 , 2020. The copyright holder for this preprint (which was not certified by peer review) is the author/funder, who has granted medRxiv a license to display the preprint in All rights reserved.

300 analyzed in two colour FC in parallel to PS. FC analyses revealed that IgG fractions 301 from severe COVID-19 patients induce remarkable changes in the PLT SSC and 302 FSC (Fig. 2.1. A+C), as well as in the distribution of CD62p/PS positivity (Fig. 2.1. 303 B+D). In contrast, the PLT population was almost non-affected after incubation with 304 IgGs from healthy controls (HCs) or ICU non-COVID-19 control patients. Overall, 305 higher percentage of double positive events was observed after incubation with IgGs 306 from ICU COVID-19 patients compared to ICU and to HCs (\% CD62p/PS positive 307 PLTs \pm SEM: $31.63 \pm 3.86$ vs. $4.04 \pm 1.16$, $p$ value 0.0007 ; and vs. $2.88 \pm 0.52$, $p$ value $308<0.0001$, respectively, Fig. 2.1. II.). Additionally, significant elevation was observed in 309 the PS single positive PLT population (\% PS positive PLTs \pm SEM: $13.17 \pm 2.05$ vs. $3102.66 \pm 0.52, p$ value $<0.0001$; and vs. $2.36 \pm 0.29$, p value 0.0002 , Fig. 2.1. I) but not in 311 the percentage of CD62p single positive PLTs (\% CD62p positive PLTS \pm SEM: $19.40 \pm 1.83$ vs. $13.53 \pm 1.90, \mathrm{p}$ value 0.1011 , Fig. 2.1. III). Next, we sought to investigate the ability of IgG fractions from patients with 314 severe COVID-19 to cause increased clot formation. PLTs from healthy individuals 315 were incubated with IgGs from ICU COVID-19 patients or ICU and HCs, added to 316 autologous whole blood samples and finally perfused throw collagen covered microfluidic channels at a shear rate of $1500 \mathrm{~s}^{-1}$ (60 dyne). As shown in Fig. 3 A, IgG 318 from severe COVID-19 patients caused increased clot formation. Overall, significantly 319 higher surface area coverage by thrombus (SAC) was observed in the presence of 320 ICU COVID-19 IgGs compared to ICU controls and HCs (mean \% SAC \pm SEM: $32113.95 \% \pm 1.55$ vs. $2.86 \pm 1.10, p$ value 0.0070 ; and vs. $2.70 \pm 0.83, p$ value 0.0002 respectively, Fig. 3 B). Together with the increased percentage of procoagulant PLTs 323 (CD62p/PS positive) in response to ICU COVID-19 IgGs, these findings might 324 provide a potential explanation for the increased thromboembolic events in severely 325 affected COVID-19 patients. 
medRxiv preprint doi: https://doi.org/10.1101/2020.12.15.20247775; this version posted December 17, 2020. The copyright holder for this preprint (which was not certified by peer review) is the author/funder, who has granted medRxiv a license to display the preprint in

All rights reserved. No reuse allowed without permission.

ICU COVID-19 IgGs cause procoagulant PLTs via crosslinking FcyRIIA

327 To further determine the underlying mechanistic pathways leading to ICU COVID-19

328 IgG induced formation of procoagulant PLTs, we next considered a potential ligation

329 of FcyRIIA by patients, sera/lgGs. For this purpose, wPLTs were pretreated with the

330 moAb IV.3. This FcyRIIA blockade resulted in marked inhibition of the antibody-

331 induced $\Delta \psi$ depolarization (FI in $\% \Delta \psi$ depolarization \pm SEM: $5.51 \pm 0.94$ vs.

332 1.18 $\pm 0.08, p$ value 0.0020 , Fig. 4.1. A) as well as significant reduction of caspase

333 activation (Ratio of cleaved caspase 3/procaspase $3 \pm$ SEM: $4.70 \pm 1.16$ vs. $1.33 \pm 0.29$,

$334 p$ value 0.0286, Fig. 4.1. B+C). Intriguingly, the blockade of FcyRIIA almost abolished

335 the changes in PLTs' FSC and SSC properties (Fig. 4.2. A+C), and markedly

336 reduced CD62p/PS double positive PLT population compared to isotype-control (\%

337 CD62p/PS positive PLTs \pm SEM: $48.91 \pm 3.05$ vs. $12.88 \pm 1.65, p$ value 0.0078, Fig. 4.2.

338 II).

Next, we analyzed the impact of FcyRIIA blockade on antibody-mediated clot

340 formation. Pretreatment of PLTs with moAb IV.3 prior to ICU COVID-19 IgG

341 incubation resulted in significant reduction of clot formation compared to isotype-

342 control (mean \% SAC \pm SEM: $16.49 \pm 1.02$ vs. $5.84 \pm 1.93$, respectively, $p$ value 0.0090 ,

343 Fig. 5 A+B). These results indicate that ICU COVID-19 IgG antibodies that are

344 present in a subgroup of severe ICU COVID-19 patients have the capability to induce

345 formation of procoagulant PLTs with increased clotting ability via crosslinking

346 FcyRIIA.

347 Calcium is pivotal for the generation of ICU COVID-19-IgG induced

348 procoagulant PLTs 
medRxiv preprint doi: https://doi.org/10.1101/2020.12.15.20247775; this version posted December 17 , 2020. The copyright holder for this preprint (which was not certified by peer review) is the author/funder, who has granted medRxiv a license to display the preprint in

All rights reserved. No reuse allowed without permission.

349 Following the detection of an ICU COVID-19 IgG-induced procoagulant PLT

350 phenotype, we sought to investigate the underlying intracellular molecular

351 mechanisms. The contribution of calcium was analyzed by the depletion of extra- and

352 intracellular calcium contents via EGTA and BAPTA, respectively. Extracellular

353 calcium depletion caused significant inhibition of $\Delta \psi$ depolarization (FI in $\% \Delta \psi$

354 depolarization \pm SEM: $3.08 \pm 0.18$ vs. $1.94 \pm 0.20, p$ value 0.0079 , Fig. 6.1 . A) as well as

355 marked reduction of caspase 3 cleavage (Ratio of cleaved caspase 3/procaspase

$3563 \pm$ SEM: $4.14 \pm 0.65$ vs. 1.50 \pm 0.20 , p value 0.0079, Fig. 6.1. B+C). Moreover,

357 depletion of extracellular calcium significantly inhibited ICU COVID-19 IgG induced

358 alterations of wPLTs' morphology (Fig. 6.2. A-D) as well as the generation of

359 CD62p/PS positive PLTs (\% CD62p/PS positive PLTs $\pm S E M: 32.89 \pm 2.77$ vs.

$360 \quad 6.42 \pm 1.21, p$ value 0.0039 , Fig. 6.2. II).

361

Similar effects were observed as depleting intracellular calcium stores. BAPTA

362 treatment resulted in significant inhibition of ICU COVID-19 IgG-induced $\Delta \Psi$

363 depolarization ( $F I$ in $\% \Delta \psi$ depolarization \pm SEM: $4.46 \pm 0.73$ vs. $0.99 \pm 0.09$, $p$ value

364 0.0039, Fig. 7.1. A) and caspase 3 cleavage (Ratio of cleaved caspase 3/procaspase

$3653 \pm$ SEM: $3.50 \pm 0.98$ vs. $0.43 \pm 0.06$, p value 0.0286 , respectively, Fig. 7.1. $B+C)$. In

366 addition, BAPTA pretreatment of WPLTs resulted in marked prevention of ICU

367 COVID-19 IgG-induced changes in FSC and SSC (Figure 7.2. A-D as well as

368 significant reduction of CD62p/PS positive PLTs (\% CD62p/PS positive PLTs:

$36929.58 \pm 3.36$ vs. $1.74 \pm 0.39$, p value 0.0020 , Fig. 7.2. II).

370 Activation of cAMP protects against ICU COVID-19 IgG induced procoagulant

$371 \quad$ PLTS

372 The interplay between the signalling pathways of the intracellular second

373 messengers, cAMP and calcium, has been shown to have an important role in 
medRxiv preprint doi: https://doi.org/10.1101/2020.12.15.20247775; this version posted December 17 , 2020. The copyright holder for this preprint (which was not certified by peer review) is the author/funder, who has granted medRxiv a license to display the preprint in All rights reserved. perpetuity.

numerous essential physiological processes during PLT activation and apoptosis (16, 17). Therefore, we investigated the role of cAMP on COVID-19 antibody-induced formation of procoagulant PLTs. Forskolin, an activator of intracellular ADC that elevates intracellular levels of cAMP, was recently reported to inhibit the formation of apoptotic PLTs in immune thrombocytopenia (18). The pretreatment of PLTs with Forskolin led to significant reduction of ICU COVID-19 IgG-induced $\Delta \psi$ depolarization (FI in $\% \Delta \psi$ depolarization \pm SEM:5.10 \pm 0.70 vs. $1.43 \pm 0.17, \mathrm{p}$ value 0.0079, Fig. 8.1 A) and caspase 3 cleavage (Ratio of cleaved caspase 3/procaspase 3+SEM: 3.74 \pm 1.14 vs. $1.01 \pm 0.14, p$ value 0.0313 , respectively, Fig. 8.1. B+C). In addition, Forskolin pretreatment of wPLTs led to reduction of ICU COVID-19 IgG-induced changes in FSC and SSC properties (Fig. 8.2. A-D) as well as to a significant inhibition of procoagulant PLT generation (\% CD62p/PS positive PLTS \pm SEM: $35.29 \pm 1.58$ vs. $12.26 \pm 2.74$, p value 0.0313 , Fig. 8.2 . II). These findings indicate that the elevation of intracellular CAMP prevents ICU COVID-19 IgG-induced formation of procoagulant PLTs.

More importantly and of high clinical interest, similar protective effect was observed with Iloprost, an already approved cAMP inducer (19). In fact, lloprost pretreatment of wPLTs led to marked reductions of ICU COVID-19 IgG-induced $\Delta \psi$ depolarization (FI of $\% \Delta \psi$ depolarization \pm SEM: $4.66 \pm 0.57$ vs. $1.77 \pm 0.32$, p value 0.0078, Fig. 9.1. A), and cleavage of caspase 3 (Ratio of cleaved caspase 3/procaspase $3 \pm$ SEM: $4.69 \pm 1.45$ vs. $2.0348 \pm 0.38$, p value 0.0156 , respectively, Fig. 9.1. $B+C)$. In addition, lloprost pretreatment led to a significant reduction of changes in PLT morphology (Fig. 9.2. A-D) as well as in the number of procoagulant CD62p/PS positive PLTs (\% CD62p/PS positive PLTs \pm SEM: $41.36 \pm 3.60$ vs. 22.22 $\pm 3.92, \mathrm{p}$ value 0.0156, Fig. 9.2. II). Noteworthy, no significant changes were 
medRxiv preprint doi: https://doi.org/10.1101/2020.12.15.20247775; this version posted December 17, 2020. The copyright holder for this preprint (which was not certified by peer review) is the author/funder, who has granted medRxiv a license to display the preprint in

All rights reserved. No reuse allowed without permission.

399 observed in the number of CD62p single positive PLTs (\% CD62p positive

400 PLTs \pm SEM: $24.48 \pm 2.2$ vs. $26.51 \pm 3.94$, p value 0.6875$)$.

401 Based on these findings we were interested whether lloprost might affect the

402 ability to form blood clots. Pretreatment of PLTs with lloprost showed a marked

403 reduction in ICU COVID-19 IgG-induced clot formation compared to vehicle (mean \%

404 SAC \pm SEM: $14.63 \pm 2.31$ vs. $3.85 \pm 0.95$, respectively, $p$ value 0.0079 , Fig. 10 . A+B).

405 These findings provide the first evidence for a potential therapeutic use of lloprost in

406 the treatment of the antibody-induced coagulopathy that is observed in COVID-19

407 disease. 
medRxiv preprint doi: https://doi.org/10.1101/2020.12.15.20247775; this version posted December 17, 2020. The copyright holder for this preprint (which was not certified by peer review) is the author/funder, who has granted medRxiv a license to display the preprint in

All rights reserved. No reuse allowed without permission.

408

409

410

411

412

413

414

\section{Discussion}

Our study showed that IgGs from patients with severe COVID-19 are able to induce procoagulant PLTs with increased potential for clot formation via crosslinking FcyRIIA in a calcium depending manner. Most importantly, we showed that CAMP activation by an approved drug, namely lloprost, can sufficiently inhibit the initiation of procoagulant PLTs and the subsequent increased clot formation. These data may have tremendous clinical implications.

Meanwhile, it is well established that COVID-19 infection is associated with systemic prothrombotic state and increased incidence of thromboembolic complications (20). However, the pre-sequelae events leading to the coagulopathy observed in COVID-19 still remains elusive. Data from our study demonstrate the presence of PLT-reactive IgG antibodies that harbour the ability to induce marked changes in PLTs in terms of increased $\Delta \psi$ depolarization, PS externalization and Pselectin expression, which are characteristic for procoagulant PLTs. A novel finding, and potentially of high clinical interest, is that antibody-mediated formation of procoagulant PLTs was associated with the clinical course as these changes progressively increased as patients needed ventilation and peaked between day 3 and 7 on ICU. Probably, the kinetic of these markers might have predictive value to monitor COVID-19-induced coagulopathy. In fact, PS externalization was recently found to be a predictive biomarker for thromboembolic complications related to cardiovascular therapeutic devices (21). In contrast to PS, conventional markers of PLT activation were declared in this study to fail the detection of early activation events leading to thrombosis.

The alterations in PLTs that were observed in our study after incubation with sera from patients with severe COVID-19 infection, such as $\Delta \psi$ disruption, caspase 3 
medRxiv preprint doi: https://doi.org/10.1101/2020.12.15.20247775; this version posted December 17 , 2020. The copyright holder for this preprint (which was not certified by peer review) is the author/funder, who has granted medRxiv a license to display the preprint in All rights reserved perpetuity.

433 cleavage and PS externalization, could be found in apoptotic as well as procoagulant

434 PLTs. The involvement of PLT apoptosis to promote prothrombotic conditions has

435 been controversially discussed. In fact, recent data suggests that apoptotic PLTs are

436 unable to promote prothrombotic conditions (10). However, a clear dissection of the

437 molecular events leading to prothrombotic PLTs is challenging since activation of the

438 apoptosis caspase pathway has been described in the late phase of agonist-induced

439 PLT activation as well as in PLTs from patients with chronic kidney disease $(22,23)$,

440 which are prone to thromboembolic events. Our findings showed that antibody-

441 mediated $\Delta \psi$ disruption and caspase cleavage is associated with the induction of a

442 CD62p/PS positive PLT population suggesting that IgG antibodies in COVID-19

443 induce procoagulant rather than apoptotic PLTs. In fact, activated PLTs were shown

444 elsewhere to be predominant in COVID-19 patients (6). In particular, CD62p positive

445 PLTs were suggested to be involved in thrombosis in COVID-19 via the interaction

446 with neutrophil granulocytes leading to NET formation and increased interaction with

447 the inflamed vessel wall. Our data showed that COVID-19 IgG-antibodies trigger a

448 PLT population with procoagulant potential. An important finding that was reinforced

449 by data from an ex vivo microfluidic circulation system which revealed an increased

450 clot formation in the presence of COVID-19 IgG-antibodies.

Motivated by these novel functional data, we thought to dissect the exact

452 mechanistic pathways involved in the COVID-19 IgG-induced procoagulant status.

453 We found that ICU COVID-19 IgG-mediated changes in wPLTs involves the ligation

454 of the immune receptor FcyRIIA. The blockade of FcyRIIA significantly inhibits ICU

455 COVID-19 IgG-induced changes in $\Delta \psi$ depolarization as well as cleavage of caspase

456 3. Most importantly, FcyRIIA blockade reduced procoagulant CD62p/PS positive

457 PLTs and subsequently inhibited COVID-19 antibody-induced ex vivo clot formation.

458 While this findings are novel for COVID-19-associated coagulopathy, the correlation 
medRxiv preprint doi: https://doi.org/10.1101/2020.12.15.20247775; this version posted December 17, 2020. The copyright holder for this preprint (which was not certified by peer review) is the author/funder, who has granted medRxiv a license to display the preprint in All rights reserved. No perpetuity.

459 between FcyRIIA ligation and increased risk for thromboembolic events is well established for heparin-induced thrombocytopenia (HIT) (24). Interestingly, the IgG antibody formation peaks in HIT within 5-10 day after exposure to heparin and is associated with PLT consumption and increased risk for thrombosis (25). Similarly, in our study the ability of ICU COVID-19 sera to induce procoagulant PLTs was most pronounced between day 3 and 7. Of note, antibody-induced alterations in PLT markers were accompanied by enhanced levels of IgG antibodies against the Spike S epitope of SARS-CoV-2.These findings might suggest a transient onset of misdirected autoimmune mechanisms that result in the emergence of PLT-reactive antibodies leading to a prothrombotic status in severe COVID-19 infection. Calcium is involved in many biological mechanistic pathways in PLTs (16). In response to PLT agonists, calcium is released from the PLT internal stores which is followed by amplifying second wave extracellular calcium influx via store (SOCE) and receptor operated calcium entry (ROCE), respectively (26). The role of calcium signalling in ITAM (immunoreceptor tyrosine-based activation motif) coupled GPVI and (hem)ITAM coupled CLEC-2 receptor signalling has been well established in the last few years (27). Additionally, FcyRIIA ligation has been shown to induce calcium mobilization via ITAM signalling prior to platelet aggregation(28). In our study, the depletion of calcium in the extracellular compartment inhibited ICU COVID-19 IgGinduced procoagulant changes. This finding indicates that alterations in SOCE or ROCE might be involved in the antibody-mediated generation of procoagulant PLTs in COVID-19. In fact, the regulative role of SOCE for procoagulant PS externalization has been previously reported, as SOCE channel inhibition resulted in reduced PS externalization in human erythroleukemia cells (29). In addition, reduced PS 
medRxiv preprint doi: https://doi.org/10.1101/2020.12.15.20247775; this version posted December 17 , 2020. The copyright holder for this preprint (which was not certified by peer review) is the author/funder, who has granted medRxiv a license to display the preprint in

485 indicating that SOCE is a major inductor of PLT PS externalization and procoagulant

PLT formation (30). A potential role of ITAM-regulated signalling leading to

procoagulant PLTs has been also suggested. Calcium depletion inhibited GP VI

induced formation of procoagulant PLTs (31). In this study, the authors proposed that distinct signalling cascades, most likely tyrosine and extracellular calcium dependent, could be involved in the formation of procoagulant PLTs. Our findings emphasize the role of extracellular calcium in FcyRIIA (ITAM) mediated procoagulant PLT formation. Another possible explanation for these finding could be the loss of distinct calciumdependent conformational properties of PLT epitopes that are targeted by COVID-19 IgG antibodies. Dimeric PLT GP IIb/IIla, the receptor for fibrinogen and well known immunogenic epitopes of PLT-reactive autoantibodies in immune thrombocytopenia (ITP), has been well characterized to be structurally dependent on extracellular calcium levels (32). Although this might be currently too speculative, the depletion of extracellular calcium might have inhibited antibody binding to such conformationsensitive epitopes on GP IIb/IIla. ICU COVID-19 IgG-induced PLT alterations were

500 dependent on extracellular as well as intracellular calcium levels. Since PLT

501 apoptosis has been described to be independent of calcium (33), our finding indicates that COVID-19 IgGs trigger FcyRIIA -mediated events that result in procoagulant PLT formation in a calcium-dependent manner. In fact, similar findings were reported by recently showing that actin-mediated PLT shape change and

505 phosphoinositide 3-kinase activity in response to FcyRIIA ligation in dependent on 506 intracellular calcium (28). The absence of ICU COVID-19 IgG-mediated PLT changes could be also due to inactivation of calcium dependent cysteine protease calpain that 508 is crucial for the conformational changes in GP IIb/IIla $(34,35)$. Another possible 
medRxiv preprint doi: https://doi.org/10.1101/2020.12.15.20247775; this version posted December 17, 2020. The copyright holder for this preprint (which was not certified by peer review) is the author/funder, who has granted medRxiv a license to display the preprint in All rights reserved. No perpetuity.

511 generation (10). Future studies could explore the exact mechanisms by which calcium contributes to procoagulant PLT formation in COVID-19.

514 the use of inducers of adenylate cyclase (ADC) that are well known to cause

515 increased cAMP levels in PLTs (36). The protective effect of cAMP was further

516 demonstrated, as Iloprost, an already approved prostacyclin derivate and ADC,

517 efficiently prevented the formation of procoagulant PLTs in response to COVID-19

518 antibodies. Finally and of high clinical importance, lloprost pretreatment of PLTs

519 markedly reduced COVID-19 IgG-induced clot formation on collagen suggesting that

520 cAMP inducers may have potential to prevent life threatening thromboembolic events

521 in COVID-19 antibody-mediated coagulopathy. Another minor finding from our

522 microfluidic system was that lloprost, although significantly inhibited antibody-

523 mediated thrombus formation, did not affect the CD62p-single positive population.

524 Since lloprost prevented clot formation, this finding might indicate that PS rather than

525 CD62p exposure on the PLT surface is pivotal to trigger the onset of thromboembolic 526 events.

Our study is subjected to some limitations. First, as an observational, monocentric study, we cannot conclude that the reported associations between IgG antibodies and changes in activation/apoptosis markers in COVID-19 are causal for the thrombosis or specific for the disease. Second, we cannot exclude the possibility

531 of remaining residual confounding or unmeasured potential confounders in our 532 mechanistic studies. Third, the low number of patients does not enable a final and 533 robust statistical analysis to assess clinical outcomes in patients with increased 534 procoagulant PLTs. Nevertheless, data presented in this study may provide a 535 background for future studies to dissect mechanisms related to PLT activation that 536 are involved in the progression of COVID-19. 
medRxiv preprint doi: https://doi.org/10.1101/2020.12.15.20247775; this version posted December $17,2020$. The copyright holder for this preprint (which was not certified by peer review) is the author/funder, who has granted medRxiv a license to display the preprint in All rights reserved. No reuse allowed without permission.

Taken together, our study shows that IgG antibodies from patients with severe

538 COVID-19 are able to stimulate FcyRIIA leading to the induction of procoagulant

539 PLTs with an increased ability of clot formation. These processes are dependent on

540 calcium and can be efficiently inhibited by cAMP inducers suggesting that ADC might

541 represent a potentially promising target to prevent thromboembolic complications in

542 COVID-19 disease.

543

544

545

546 
medRxiv preprint doi: https://doi.org/10.1101/2020.12.15.20247775; this version posted December 17, 2020. The copyright holder for this preprint (which was not certified by peer review) is the author/funder, who has granted medRxiv a license to display the preprint in All rights reserved. No reuse allowed without permission.

\section{Author contributions}

549 J.Z., K.A., T.B. and P.R. designed the study. P.R. and H.H. were responsible for the

550 treatment of the patients. K.A. and H.H. collected and analyzed the clinical data. J.Z., 551 K.A., H.J., L.P., A.S. and A.W. performed the experiments. J.Z., K.A., H.J., L.P., A.S. 552 and A.W. collected the data. J.Z., K.A., H.J., L.P., A.S., A.W., V.M., P.R. and T.B.

553 analyzed the data, interpreted the results and wrote the manuscript. All authors read 554 and approved the manuscript.

556 Conflict of interest

557 The authors have no conflict of Interests.

\section{Acknowledgements}

This work was supported by grants from the "Ministerium für Wissenschaft,

561 Forschung und Kunst Baden-Württemberg" to J.Z. and T.B. and from the Herzstiftung

562 to T.B. (BA5158/4 and TSG-Study) and TÜFF-Gleichstellungsförderung to K.A.

563 (2563-0-0). We thank Karoline Weich for her excellent technical support. The authors

564 thank Susanne Staub for editing the article as native English speaker.

565

566

567

568

569

570 
medRxiv preprint doi: https://doi.org/10.1101/2020.12.15.20247775; this version posted December 17, 2020. The copyright holder for this preprint (which was not certified by peer review) is the author/funder, who has granted medRxiv a license to display the preprint in

All rights reserved. No reuse allowed without permission.

\section{$571 \quad$ Figure legends}

572 Fig. 1-ICU COVID-19 patient serum induced effects on PLTs during disease.

573 (A+B) ICU COVID-19 $(n=26)$ or ICU non-COVID-19 control $(n=5)$ patient serum

574 induced changes in $\Delta \psi$ as well as PS externalization in wPLTs were analyzed by FC.

575 (C+D) Sera of 4 ICU COVID-19 patients were collected for up to 14 days during

576 hospitalization and analyzed for their ability to induce changes in $\Delta \psi$ as well as PS

577 externalization in WPLTs via FC. (E) Representative WB image of detected cleaved

578 caspase 3 (cleaved-) and procaspase 3 (pro-) levels in wPLTs that were incubated

579 with follow up sera of one ICU COVID-19 patient (indicated in C+D). (F)

580 Densitometric analysis of cleaved caspase 3/procaspase 3 ratios in wPLTs that were 581 incubated with follow up sera of ICU COVID-19 patients ( $n=4$, [indicated in $C+D$ ])

582 normalized to control. $\alpha$-Tubulin served as loading control. Data are presented as

583 mean \pm SEM of the measured fold increase compared to control. ns, not significant;

$584{ }^{*} \mathrm{p}<0.05,{ }^{*} \mathrm{p}<0.01,{ }^{* \star} \mathrm{p}<0.001$ and ${ }^{\star \star \star *} \mathrm{p}<0.0001$. The number of patient sera tested is

585 reported in each graph. Dot lines in (A+B) represent the calculated cutoffs

586 determined testing sera from healthy donors as mean of fold increase (FI)+2xSEM.

$587 \mathrm{HC}$, healthy control; $\Delta \psi$, inner mitochondrial transmembrane potential; $\mathrm{N}$, number of

588 HCs or patients; PS, phosphatidylserine.

589 Fig. 2-ICU COVID-19 IgGs induce procoagulant PLTs and increased clot

590 formation.

591 Fig. 2.1. (A+C) Representative FC plots of wPLTs' FSC vs. SSC properties after HC

592 or ICU COVID-19 IgG incubation. (B+D) Following HC or ICU COVID-19 IgG

593 incubation, CD42a positive gated wPLTs were analyzed for PS externalization and

594 expression of CD62p via Annexin V-FITC and CD62p-APC antibody staining, 
medRxiv preprint doi: https://doi.org/10.1101/2020.12.15.20247775; this version posted December 17, 2020. The copyright holder for this preprint (which was not certified by peer review) is the author/funder, who has granted medRxiv a license to display the preprint in

All rights reserved. No reuse allowed without permission.

595 respectively. Fig. 2.1. (I-IV) represent quantitative gate distribution of CD42a positive 596 events as indicated in Fig. 2.1. (B+D). Data are shown as percentage \pm SEM of 597 Annexin V-FITC and or CD62p-APC positive labeled wPLTs after incubation with HC 598 (n=8), ICU non-COVID-19 $(n=5)$ or ICU COVID-19 IgG $(n=10)$. ns, not significant; $599{ }^{*} p<0.05,{ }^{* \star} p<0.01,{ }^{* \star *} p<0.001$ and ${ }^{* \star * *} p<0.0001$. The number of patients and healthy 600 donors tested is reported in each graph. $\mathrm{HC}$, healthy control; N, number of HCs or 601 patients; PS, phosphatidylserine.

Fig. 3-ICU COVID-19 IgG cause increased clot formation on collagen.

603 (A) PRP from healthy individuals with the blood group O was incubated with HC 604 ( $n=6)$, ICU non-COVID-19 control $(n=3)$ or ICU COVID-19 IgG $(n=10)$, labelled with 605 FITC conjugated calcein and perfused through microfluidic channels at a shear rate 606 of $1500^{-1}$ ( 60 dyne) for 5 min after reconstitution into autologous whole blood. Images 607 were aquired at $\times 20$ magnification in the fluorescent (upper panel) as well as in the

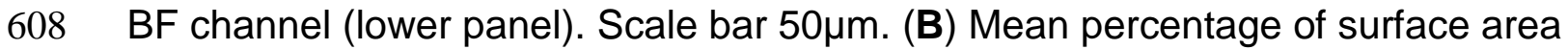
covered (mean \% SAC) \pm SEM by thrombus in the presence of HC ( $n=6)$, ICU nonCOVID-19control $(n=3)$ and ICU COVID-19 $(n=10)$ IgG after 5 min perfusion time. ns, 611 not significant; ${ }^{*} p<0.05,{ }^{* \star} p<0.01,{ }^{* \star *} p<0.001$ and ${ }^{* \star \star *} p<0.0001$. The number of 612 patients and healthy donors tested is reported in each graph. $\mathrm{HC}$, healthy control; $\mathrm{N}$, 613 number of HCs or patients. Fig. 4-ICU COVID-19 IgG induced formation of procoagulant PLTs is FcyRIIA dependent.

Fig. 4.1. (A) ICU COVID-19 patient serum $(n=10)$ induced changes of $\Delta \Psi$ in WPLTS

617 were analyzed in the presence or absence of moAb IV.3 via FC. Data are presented 618 as mean \pm SEM of the measured fold increase compared to control. $(\mathbf{B}+\mathbf{C})$ 
medRxiv preprint doi: https://doi.org/10.1101/2020.12.15.20247775; this version posted December 17, 2020. The copyright holder for this preprint (which was not certified by peer review) is the author/funder, who has granted medRxiv a license to display the preprint in

All rights reserved. No reuse allowed without permission.

619 Representative WB image of detected cleaved caspase 3 (cleaved-) and procaspase

6203 (pro-) levels in wPLTs that were incubated with ICU COVID-19 IgG $(n=4)$ in the

621 presence or absence of moAb IV.3. $\alpha$-Tubulin served as loading control. (C)

622 Densitometric analysis of cleaved caspase 3/procaspase 3 ratios from immunoblots

623 as indicated in (B, $n=4)$ normalized to control. Fig. 4.2. $(\mathbf{A}+\mathbf{C})$ Representative FC

624 plots of wPLTs' FSC vs. SSC after ICU COVID-19 IgG incubation in IV.3 pretreated

625 wPLTs. (B+D) Gate distribution of CD42a positive PS (Annexin V-FITC) externalizing

626 and CD62p (CD62p-APC) expressing wPLTs after ICU COVID-19 IgG incubation in

627 isotype control or IV.3 pretreated wPLTs. Fig. 4.2. (I-IV) shows quantitative gate

628 distributions of wPLTs with or without IV.3 pretreatment, after ICU COVID-19 IgG

629 incubation as shown in Fig. 4.2. (B+D). Data are presented as percentage \pm SEM of

630 Annexin V-FITC and or CD62p-APC positive labeled wPLTs after incubation with HC

$631(n=3)$ or ICU COVID-19 IgG $(n=8)$ in the presence or absence of moAb IV.3. ns, not

632 significant; ${ }^{*} p<0.05,{ }^{* *} p<0.01,{ }^{* *} p<0.001$ and ${ }^{* \star * *} p<0.0001$. The number of patients

633 and healthy donors tested is reported in each graph. $\mathrm{HC}$, healthy control; N, number

634 of HCs or patients; PS, phosphatidylserine.

635 Fig. 5-FcyRIIA inhibition prevents ICU COVID-19 IgG induced increased clot

636 formation.

637 (A) PRP from healthy individuals with the blood group O was incubated with HC

$638(\mathrm{n}=2)$ or ICU COVID-19 IgG ( $\mathrm{n}=3$ patients) in the presence of moAb IV.3 or isotype

639 control (moAb) and perfused through microfluidic channels at a shear rate of $1500^{-1}$

640 (60 dyne) for 5 min. Images were aquired at x20 magnification in fluorescent (upper

641 panel) as well as in the BF channel (lower panel). Scale bar $50 \mu \mathrm{m}$. (B) mean \%

642 SAC \pm SEM induced by HC $(n=2)$ or ICU COVID-19 IgG $(n=3)$ in the presence or

643 absence of moAb IV.3 or isotype control (moAb). ns, not significant; * $p<0.05$, 
medRxiv preprint doi: https://doi.org/10.1101/2020.12.15.20247775; this version posted December 17, 2020. The copyright holder for this preprint (which was not certified by peer review) is the author/funder, who has granted medRxiv a license to display the preprint in All rights reserved perpetuity.

$644{ }^{* \star} p<0.01,{ }^{* \star} p<0.001$ and ${ }^{* \star *} p<0.0001$. The number of patients and healthy donors 645 tested is reported in each graph. moAb, monoclonal isotype control; HC, healthy 646 control; N, number of HCs or patients

647 Fig. 6-ICU COVID-19 IgG induced formation of procoagulant PLTs is dependent on extracellular calcium.

Fig. 6.1. (A) FC assessment of ICU COVID-19 IgG (n=5) induced changes of $\Delta \Psi$ in wPLTs that were pretreated with EGTA $(1 \mathrm{mM})$ or vehicle. Data are presented as mean $\pm S E M$ of the measured fold increase compared to control. $(\mathbf{B}+\mathbf{C})$

652 Representative WB image of detected cleaved caspase 3 (cleaved-) and procaspase 3 (pro-) levels in EGTA (1 mM) vehicle pretreated wPLTs that were incubated with ICU COVID-19 IgG ( $n=6)$, respectively. $\alpha$-Tubulin served as loading control. (C)

Densitometric analysis of immunoblots indicated in (B) for cleaved caspase 3/procaspase 3 ratios from WB data as indicated in $(\mathbf{B},[n=5])$ normalized to control.

Fig. 6.2. (A+C) Representative FC plots of wPLTs' FSC vs. SSC after ICU COVID(CD62p-APC) expressing wPLTs after ICU COVID-19 IgG incubation in EGTA (1mM) or vehicle pretreated wPLTs. Fig. 6.2. (B+D) Gate distribution of CD42a positive PS 662 (Lactadherin-FITC) externalizing and CD62p (CD62p-APC) expressing wPLTs after ICU COVID-19 IgG incubation in EGTA $(1 \mathrm{mM})$ or vehicle containing wPLTs. Fig. 
medRxiv preprint doi: https://doi.org/10.1101/2020.12.15.20247775; this version posted December 17, 2020. The copyright holder for this preprint (which was not certified by peer review) is the author/funder, who has granted medRxiv a license to display the preprint in

All rights reserved. No reuse allowed without permission.

669 tested is reported in each graph. HC, healthy control; N, number of HCs or patients;

670 PS, phosphatidylserine.

671 Fig. 7-Depletion of intracellular calcium abrogates ICU COVID-19 IgG induced

672 procoagulant PLT formation.

673 Fig. 7.1 (A) ICU COVID-19 IgG ( $\mathrm{n}=9)$ induced changes of $\Delta \psi$ in wPLTs were

674 analyzed in the presence or absence of the intracellular calcium chelator BAPTA (20

$675 \mu \mathrm{M})$. (B) Representative WB image of cleaved caspase 3 (cleaved-) and procaspase

6763 (pro-) were detected with anti-caspase 3 antibody in wPLTs that were incubated

677 with ICU COVID-19 IgG in BAPTA $(20 \mu \mathrm{M})$ or vehicle pretreated wPLTs. $\alpha$.Tubulin

678 served as loading control. (C) Densitometric analysis of cleaved caspase

$6793 /$ procaspase 3 ratios from immunoblots (indicated in $B,[n=4]$ ) normalized to control.

680 Fig. 7.2. (A+C) FC plots of WPLTs' FSC and. SSC after ICU COVID-19 IgG

681 incubation in vehicle or BAPTA $(20 \mu \mathrm{M})$ preloaded wPLTs. (B+D) FC plots of CD42a

682 positive gated WPLTs that were incubated with ICU COVID-19 IgG in vehicle or in

683 BAPTA $(20 \mu \mathrm{M})$ preloaded wPLTs. Fig. 7.2.(I-IV) quantitative gate distribution of

684 CD42a positive wPLTs based on the gate settings shown in Fig. 7.2. (B+D). Data are 685 shown as percentage \pm SEM of Lactadherin-FITC and or CD62p-APC positive labeled 686 wPLTs after HC $(n=3)$ or ICU COVID-19 IgG $(n=10)$ incubation in normal or BAPTA

$687(20 \mu \mathrm{M})$ preloaded wPLTs. Ns, not significant; ${ }^{\star} p<0.05,{ }^{\star \star} p<0.01,{ }^{\star \star \star} p<0.001$ and $688 * \star \star * x<0.0001$. The number of patients and healthy donors tested is reported in each 689 graph. HC, healthy control; N, number of HCs or patients, PS; phosphatidylserine.

690 Fig. 8-Forskolin protects ICU COVID-19 IgG induced procoagulant PLT

691 formation. 
medRxiv preprint doi: https://doi.org/10.1101/2020.12.15.20247775; this version posted December 17, 2020. The copyright holder for this preprint (which was not certified by peer review) is the author/funder, who has granted medRxiv a license to display the preprint in

All rights reserved. No reuse allowed without permission.

692 Fig. 8.1. (A) FC analysis of ICU COVID-19 IgG ( $n=5$ patients) induced changes in $\Delta \psi$ 693 of wPLTs, that were pretreated with vehicle or the ADC inductor Forskolin $(2.25 \mu \mathrm{M})$

694 for $30 \mathrm{~min}$ at $37^{\circ} \mathrm{C}$. Data are presented as mean \pm SEM of the measured fold increase

695 compared to control. (B) Representative WB image of cleaved caspase 3 (cleaved-)

696 and procaspase 3 (pro-) levels detected in wPLTs that were incubated with ICU

697 COVID-19 IgG in vehicle or Forskolin $(2.25 \mu \mathrm{M})$ pretreated wPLTs. $\alpha$-Tubulin served

698 as loading control. (C) Densitometric assesed ratios of cleaved caspase

699 3/procaspase 3 (as indicated in $\mathbf{B}[\mathrm{n}=6]$ ) normalized to control. Fig. 8.2. ( $\mathbf{A}+\mathbf{C})$ FC

700 plots of WPLTs' FSC vs. SSC after ICU COVID-19 IgG incubation in vehicle or

701 Forskolin $(2.25 \mu \mathrm{M})$ pretreted wPLTs. (B+D) Gate distribution of CD42a positive

702 wPLTs that were incubated with ICU COVID-19 IgG vehicle or Forskolin $(2.25 \mu \mathrm{M})$

703 pretreated wPLTs. Fig. 8.2. (I-IV) Quantitative distribution of CD42a positive wPLTs

704 based on the gate settings shown in Fig. 8.2. (B+D). Data are shown as percentage

$705 \pm$ SEM of Annexin V-FITC and or CD62p-APC positive labeled wPLTs that were

706 incubated with IgGs from HC $(n=3)$ or ICU COVID-19 IgG $(n=6)$ in vehicle or

707 Forskolin $(2.25 \mu \mathrm{M})$ pretreated wPLTs. ns, not significant; ${ }^{\star} \mathrm{p}<0.05,{ }^{* \star} p<0.01$,

$708{ }^{* * *} p<0.001$ and ${ }^{* * *} p<0.0001$. The number of patients and healthy donors tested is

709 reported in each graph. $\mathrm{HC}$, healthy control; N, number of HCs or patients; PS,

710 phosphatidylserine.

712 Fig. 9-CAMP elevation via lloprost prevents ICU COVID-19 IgG induced

713 procoagulant PLTs.

714 Fig. 9.1. (A) Changes in $\Delta \psi$ depolarization induced by ICU COVID-19 IgG ( $\mathrm{n}=8$

715 patients) were analyzed in vehicle or lloprost (20 nM) pretreated WPLTs via FC. Data 
medRxiv preprint doi: https://doi.org/10.1101/2020.12.15.20247775; this version posted December 17 , 2020. The copyright holder for this preprint (which was not certified by peer review) is the author/funder, who has granted medRxiv a license to display the preprint in

All rights reserved. No reuse allowed without permission.

are presented as mean \pm SEM of the measured fold increase compared to control.

Representative WB image of detected caspase 3 (cleaved-) and procaspase 3 (pro-) levels in WPLTs that were pretreated with vehicle or lloprost $(20 \mathrm{nM})$ prior to ICU COVID-19 IgG incubation. $\alpha$-Tubulin served as loading control. (C) Densitometric analysis of cleaved caspase 3/procaspase 3 ratios from the WB data (indicated in B, $[n=7])$ normalized to control. Fig. 9.2. $(A+C) F C$ detected changes in wPLTs' FSC vs. SSC properties after ICU COVID-19 IgG incubation in vehicle or lloprost (20 nM) pretreated wPLTs. Fig. 9.2. (B+D) $(\mathbf{E}+\mathbf{G})$ Gate distribution of CD42a positive vehicle or lloprost $(20 \mathrm{nM})$ pretreated wPLTs that were incubated with ICU COVID-19 IgG.

Fig. 9.2. (I-IV) Quantitative distribution of the CD42a positive WPLT population based on the gate settings shown in Fig. 9.2. (B+D). Data are shown as percentage $\pm S E M$ of Annexin V-FITC and or CD62p-APC positive labeled wPLTs that were incubated with HC $(n=3)$ or ICU COVID-19 IgG $(n=6)$ in vehicle or lloprost $(20 \mathrm{nM})$ pretreated wPLTs. ns, not significant; ${ }^{\star} p<0.05,{ }^{* \star} p<0.01,{ }^{* \star \star} p<0.001$ and ${ }^{* \star \star \star} p<0.0001$. The number of patients and healthy donors tested is reported in each graph. $\mathrm{HC}$, healthy control; N, number of HCs or patients; PS, phosphatidylserine.

\section{Fig. 10-lloprost inhibits ICU COVID-19 IgG induced increased clot formation.}

(A) PRP from healthy individuals with the blood group O was incubated with $\mathrm{HC}$ $(n=3)$ or ICU COVID-19 IgG $(n=5)$ in the presence of vehicle or lloprost $(20 \mathrm{nM})$. After resonstituion into autologous whole blood, samples were perfused through microfluidic channels at a shear rate of $1500^{-1}$ (60 dyne) for 5 min. Pictures were aquired at $\times 20$ magnification in fluorescent (upper panel) as well as in the BF channel

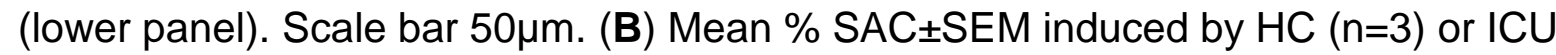
COVID-19 IgG $(n=5)$ in the presence of vehicle or lloprost $(20 \mathrm{nM})$. ns, not significant; ${ }^{*} p<0.05,{ }^{* \star} p<0.01,{ }^{* \star} p<0.001$ and ${ }^{* \star * *} p<0.0001$. The number of patients and healthy 
medRxiv preprint doi: https://doi.org/10.1101/2020.12.15.20247775; this version posted December 17 , 2020. The copyright holder for this preprint (which was not certified by peer review) is the author/funder, who has granted medRxiv a license to display the preprint in

donors tested is reported in each graph. $\mathrm{HC}$, healthy control; $\mathrm{N}$, number of $\mathrm{HCs}$ or

patients; PS, phosphatidylserine.

\section{References:}

1. Zhou F, Yu T, Du R, Fan G, Liu Y, Liu Z, et al. Clinical course and risk factors for mortality of adult inpatients with COVID-19 in Wuhan, China: a retrospective cohort study. Lancet.

750

751

752

753

754 2020;395(10229):1054-62.

2. Hanff TC, Mohareb AM, Giri J, Cohen JB, Chirinos JA. Thrombosis in COVID-19. Am J Hematol. 2020;95(12):1578-89.

3. Iba T, Levy JH, Levi M, Connors JM, Thachil J. Coagulopathy of Coronavirus Disease 2019. Crit Care Med. 2020;48(9):1358-64.

4. Henry BM, Vikse J, Benoit S, Favaloro EJ, Lippi G. Hyperinflammation and derangement of renin-angiotensin-aldosterone system in COVID-19: A novel hypothesis for clinically suspected hypercoagulopathy and microvascular immunothrombosis. Clin Chim Acta. 2020;507:167-73. 5. Hottz ED, Azevedo-Quintanilha IG, Palhinha L, Teixeira L, Barreto EA, Pao CRR, et al. Platelet activation and platelet-monocyte aggregate formation trigger tissue factor expression in patients with severe COVID-19. Blood. 2020;136(11):1330-41.

6. Manne BK, Denorme F, Middleton EA, Portier I, Rowley JW, Stubben C, et al. Platelet gene expression and function in patients with COVID-19. Blood. 2020;136(11):1317-29.

7. de Witt SM, Verdoold R, Cosemans JM, Heemskerk JW. Insights into platelet-based control of coagulation. Thromb Res. 2014;133 Suppl 2:S139-48.

8. Swieringa F, Spronk HMH, Heemskerk JWM, van der Meijden PEJ. Integrating platelet and coagulation activation in fibrin clot formation. Res Pract Thromb Haemost. 2018;2(3):450-60.

9. Agbani EO, Poole AW. Procoagulant platelets: generation, function, and therapeutic targeting in thrombosis. Blood. 2017;130(20):2171-9.

768 10. Reddy EC, Rand ML. Procoagulant Phosphatidylserine-Exposing Platelets in vitro and in vivo.

769 Front Cardiovasc Med. 2020;7:15.

770 11. Hua VM, Chen VM. Procoagulant platelets and the pathways leading to cell death. Semin

771 Thromb Hemost. 2015;41(4):405-12.

772

773

774

775

776

12. Greinacher A, Michels I, Kiefel V, Mueller-Eckhardt C. A rapid and sensitive test for diagnosing heparin-associated thrombocytopenia. Thromb Haemost. 1991;66(6):734-6.

13. Marini I, Zlamal J, Faul C, Holzer U, Hammer S, PelzI L, et al. Autoantibody-mediated desialylation impairs human thrombopoiesis and platelet life span. Haematologica. 2019.

14. Mangin PH, Gardiner EE, Nesbitt WS, Kerrigan SW, Korin N, Lam WA, et al. In vitro flow based systems to study platelet function and thrombus formation: Recommendations for standardization: Communication from the SSC on Biorheology of the ISTH. J Thromb Haemost. 2020;18(3):748-52. 15. Huang C, Wang Y, Li X, Ren L, Zhao J, Hu Y, et al. Clinical features of patients infected with 2019 novel coronavirus in Wuhan, China. Lancet. 2020;395(10223):497-506.

16. Mammadova-Bach E, Nagy M, Heemskerk JWM, Nieswandt B, Braun A. Store-operated calcium entry in thrombosis and thrombo-inflammation. Cell Calcium. 2019;77:39-48.

17. Nagy Z, Smolenski A. Cyclic nucleotide-dependent inhibitory signaling interweaves with activating pathways to determine platelet responses. Res Pract Thromb Haemost. 2018;2(3):558-71. 18. Zhao L, Liu J, He C, Yan R, Zhou K, Cui Q, et al. Protein kinase A determines platelet life span and survival by regulating apoptosis. J Clin Invest. 2017;127(12):4338-51. 
medRxiv preprint doi: https://doi.org/10.1101/2020.12.15.20247775; this version posted December 17 , 2020. The copyright holder for this preprint (which was not certified by peer review) is the author/funder, who has granted medRxiv a license to display the preprint in

All rights reserved. No reuse allowed without permission.

19. Fisch A, Michael-Hepp J, Meyer J, Darius H. Synergistic interaction of adenylate cyclase activators and nitric oxide donor SIN-1 on platelet cyclic AMP. Eur J Pharmacol. 1995;289(3):455-61. 20. Tang N, Li D, Wang X, Sun Z. Abnormal coagulation parameters are associated with poor prognosis in patients with novel coronavirus pneumonia. J Thromb Haemost. 2020;18(4):844-7. 21. Roka-Moiia Y, Walk R, Palomares DE, Ammann KR, Dimasi A, Italiano JE, et al. Platelet Activation via Shear Stress Exposure Induces a Differing Pattern of Biomarkers of Activation versus Biochemical Agonists. Thromb Haemost. 2020;120(5):776-92.

22. Shcherbina A, Remold-O'Donnell E. Role of caspase in a subset of human platelet activation responses. Blood. 1999;93(12):4222-31.

23. Bonomini M, Dottori S, Amoroso L, Arduini A, Sirolli V. Increased platelet phosphatidylserine exposure and caspase activation in chronic uremia. J Thromb Haemost. 2004;2(8):1275-81.

24. Chong BH, Fawaz I, Chesterman CN, Berndt MC. Heparin-induced thrombocytopenia: mechanism of interaction of the heparin-dependent antibody with platelets. $\mathrm{Br} \mathrm{J}$ Haematol. 1989;73(2):235-40.

25. Warkentin TE. Clinical picture of heparin-induced thrombocytopenia (HIT) and its differentiation from non-HIT thrombocytopenia. Thromb Haemost. 2016;116(5):813-22.

26. Rink TJ, Sage SO. Calcium signaling in human platelets. Annu Rev Physiol. 1990;52:431-49.

27. Rayes J, Watson SP, Nieswandt B. Functional significance of the platelet immune receptors GPVI and CLEC-2. J Clin Invest. 2019;129(1):12-23.

28. Barkalow KL, Falet H, Italiano JE, Jr., van Vugt A, Carpenter CL, Schreiber AD, et al. Role for phosphoinositide 3-kinase in Fc gamma RIIA-induced platelet shape change. Am J Physiol Cell Physiol. 2003;285(4):C797-805.

29. Kunzelmann-Marche C, Freyssinet JM, Martinez MC. Regulation of phosphatidylserine transbilayer redistribution by store-operated Ca2+ entry: role of actin cytoskeleton. J Biol Chem. 2001;276(7):5134-9.

30. Bergmeier W, Oh-Hora M, McCarl CA, Roden RC, Bray PF, Feske S. R93W mutation in Orai1 causes impaired calcium influx in platelets. Blood. 2009;113(3):675-8.

31. Heemskerk JW, Vuist WM, Feijge MA, Reutelingsperger CP, Lindhout T. Collagen but not fibrinogen surfaces induce bleb formation, exposure of phosphatidylserine, and procoagulant activity of adherent platelets: evidence for regulation by protein tyrosine kinase-dependent $\mathrm{Ca} 2+$ responses. Blood. 1997;90(7):2615-25.

32. Tomiyama $\mathrm{Y}, \mathrm{Kosugi} \mathrm{S}$. Autoantigenic epitopes on platelet glycoproteins. Int J Hematol. 2005;81(2):100-5.

33. Schoenwaelder SM, Yuan Y, Josefsson EC, White MJ, Yao Y, Mason KD, et al. Two distinct pathways regulate platelet phosphatidylserine exposure and procoagulant function. Blood. 2009;114(3):663-6.

34. Mattheij NJ, Gilio K, van Kruchten R, Jobe SM, Wieschhaus AJ, Chishti AH, et al. Dual mechanism of integrin alphallbbeta3 closure in procoagulant platelets. J Biol Chem. 2013;288(19):13325-36.

35. Kulkarni S, Jackson SP. Platelet factor XIII and calpain negatively regulate integrin alphallbbeta3 adhesive function and thrombus growth. J Biol Chem. 2004;279(29):30697-706. 36. Smolenski A. Novel roles of CAMP/cGMP-dependent signaling in platelets. J Thromb Haemost. 2012;10(2):167-76. 
medRxiv preprint doi: https://doi.org/10.1101/2020.12.15.20247775; this version posted December $17,2020$. The copyright holder for this preprint (which was not certified by peer review) is the author/funder, who has granted medRxiv a license to display the preprint in perpetuity.

All rights reserved. No reuse allowed without permission.

Figure 1

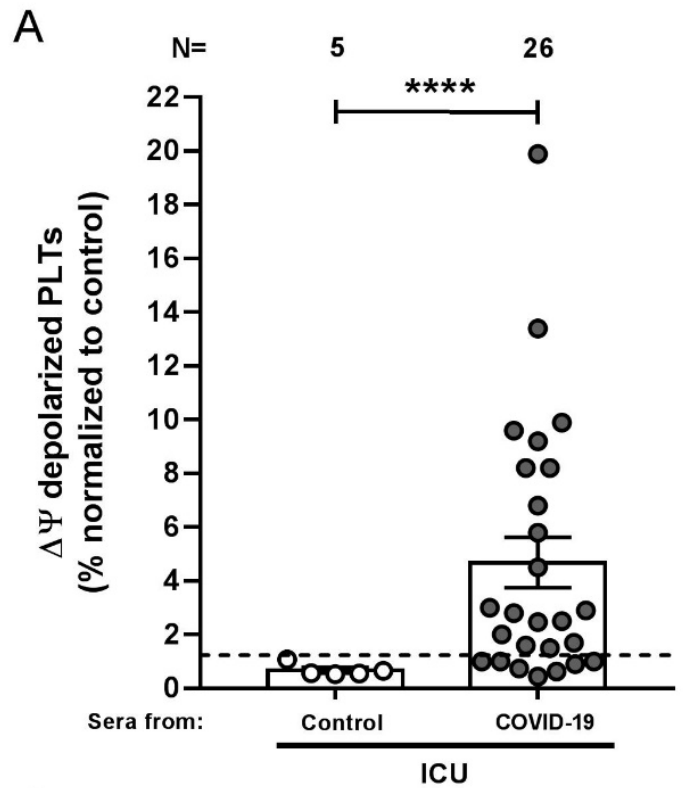

C

E
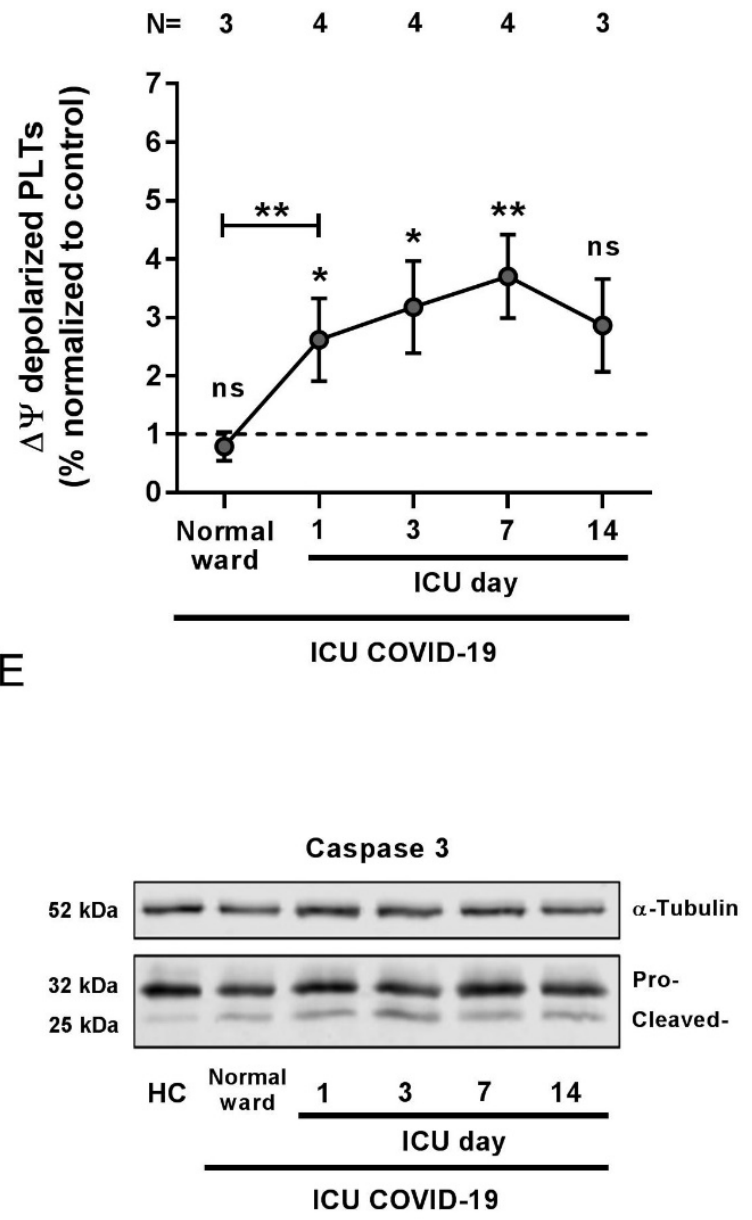

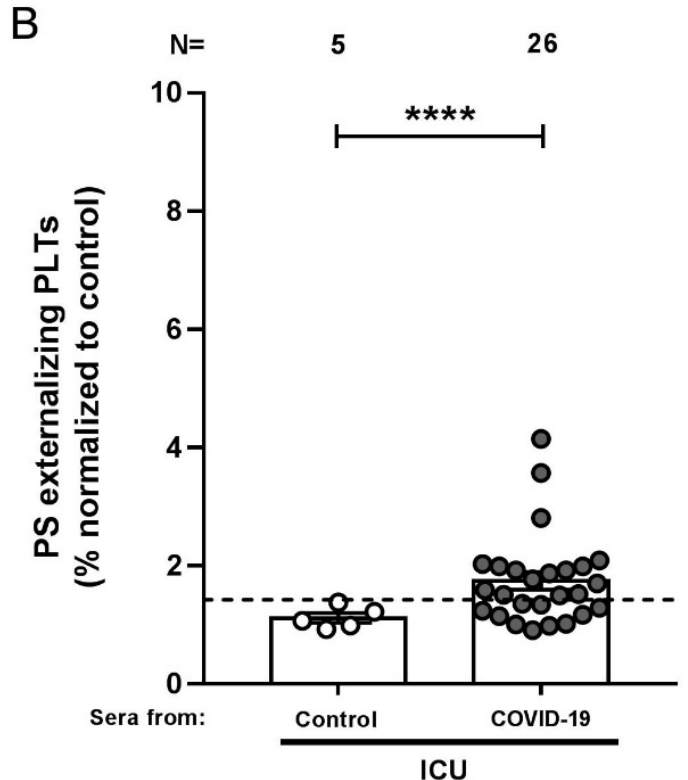

D

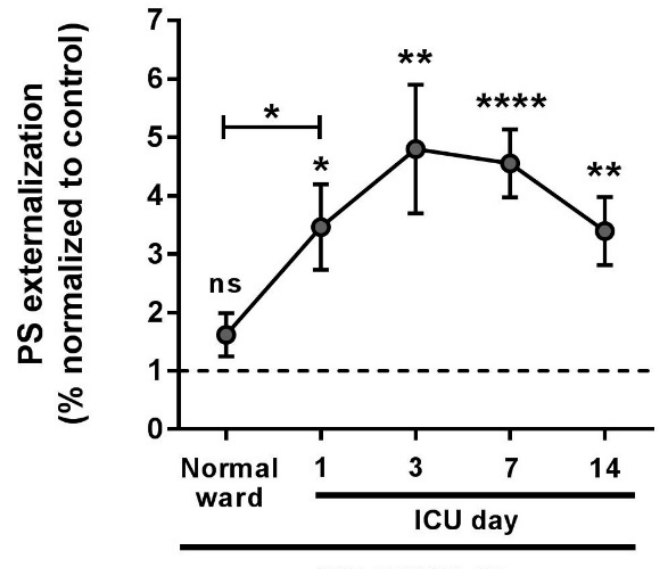

$\mathrm{F}$

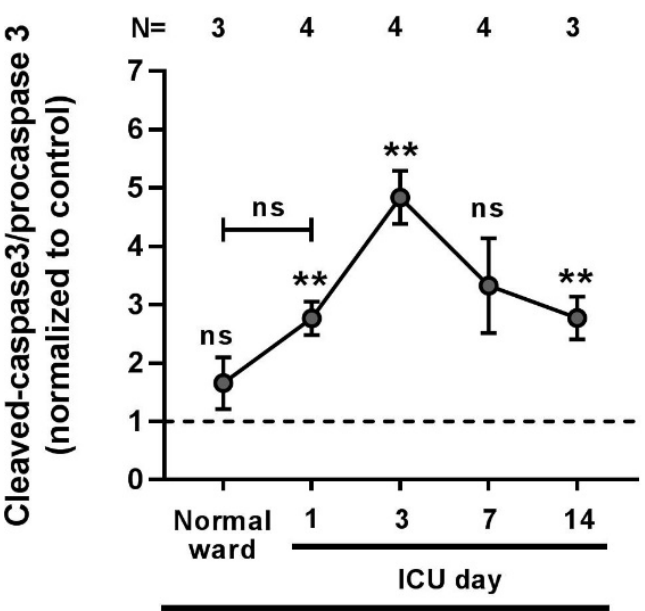

ICU COVID-19 
Figure 2.1.

A

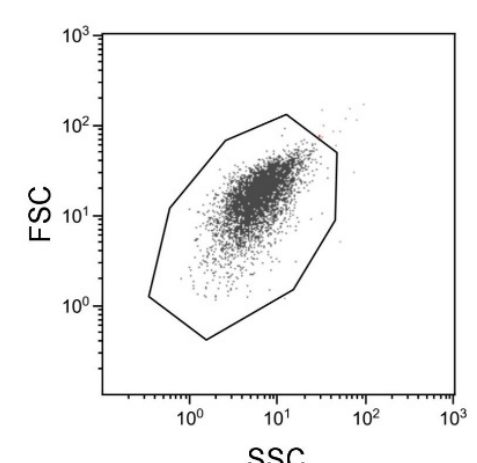

B

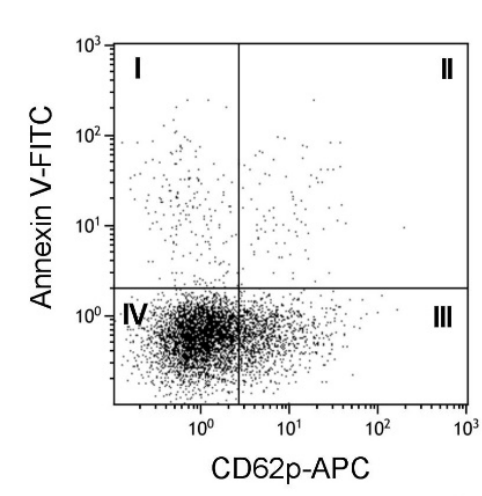

HC

C

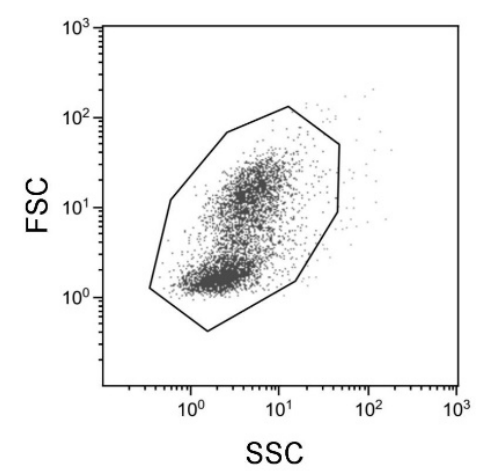

D

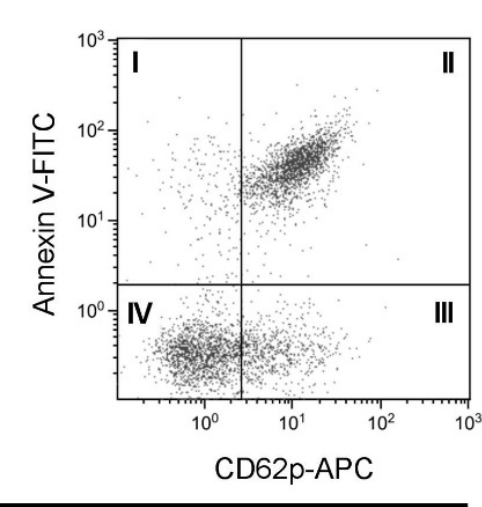

ICU COVID-19

Figure 2.1.

I

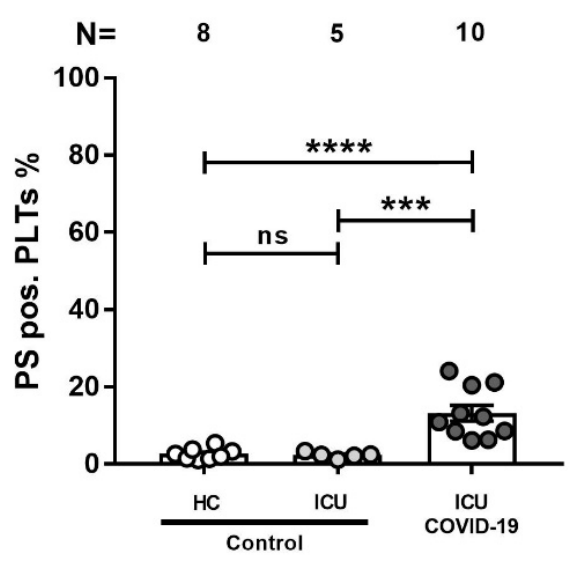

IV

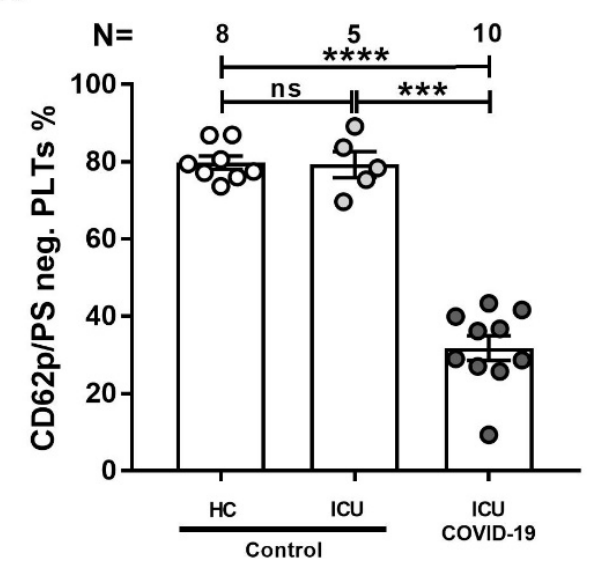

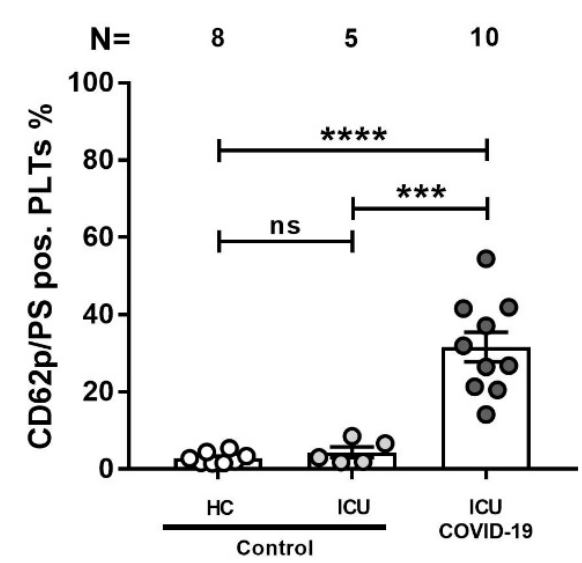

III

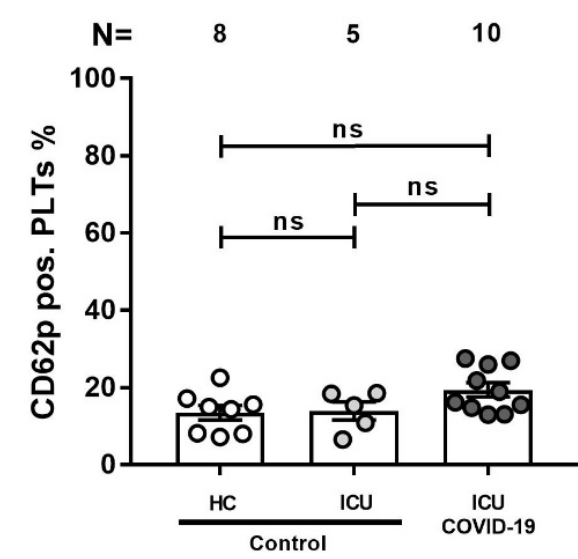


Figure 3

A

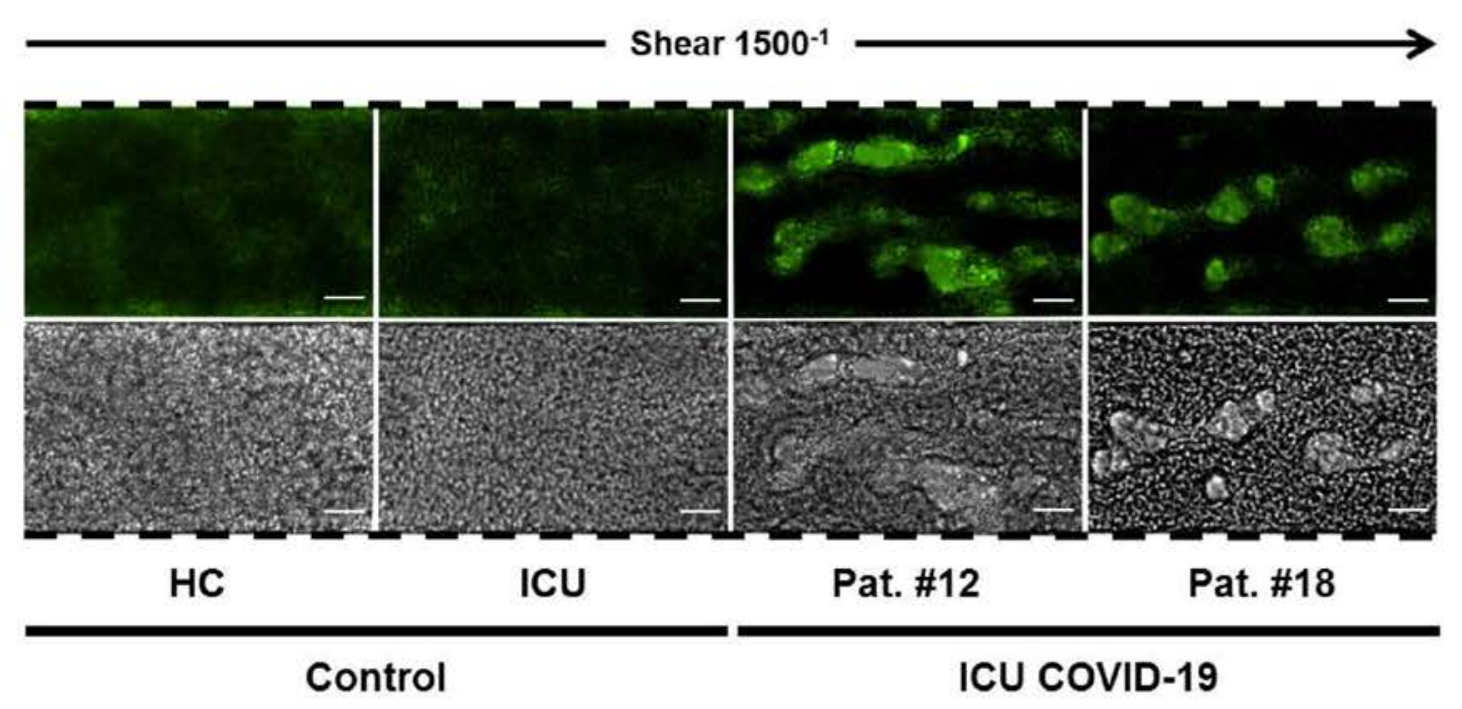

B

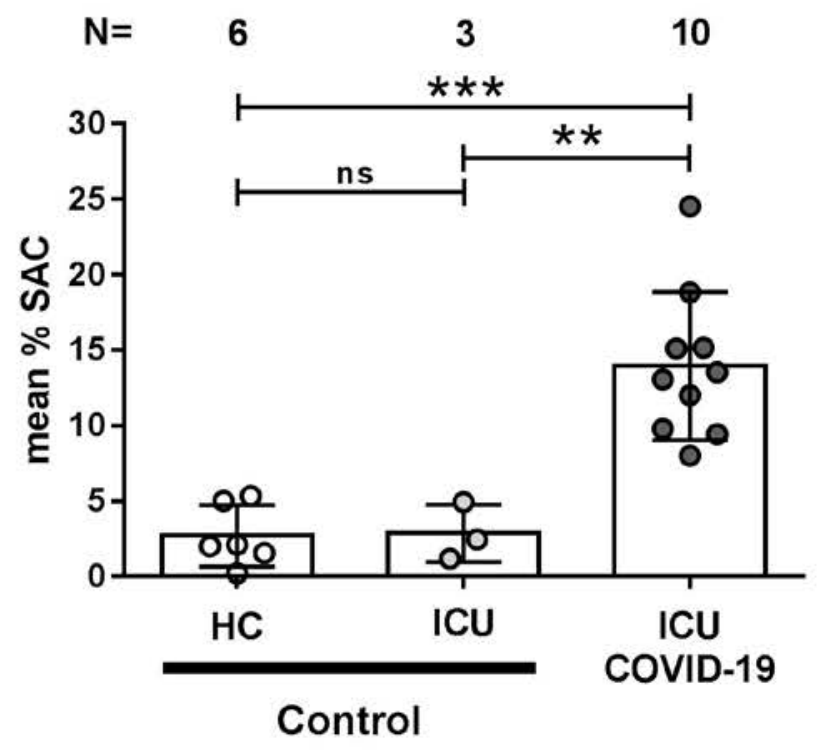


Figure 4.1.

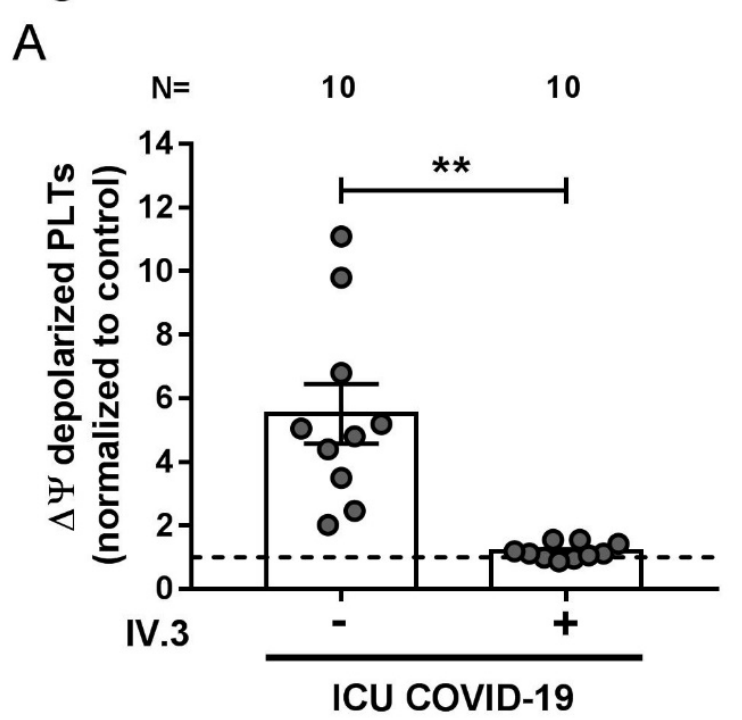

B

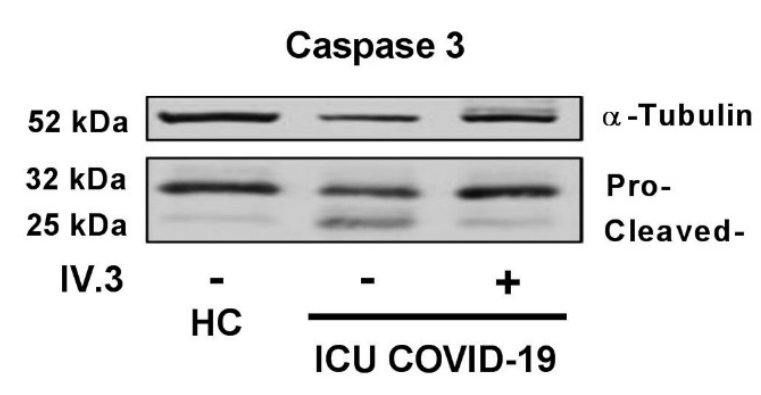

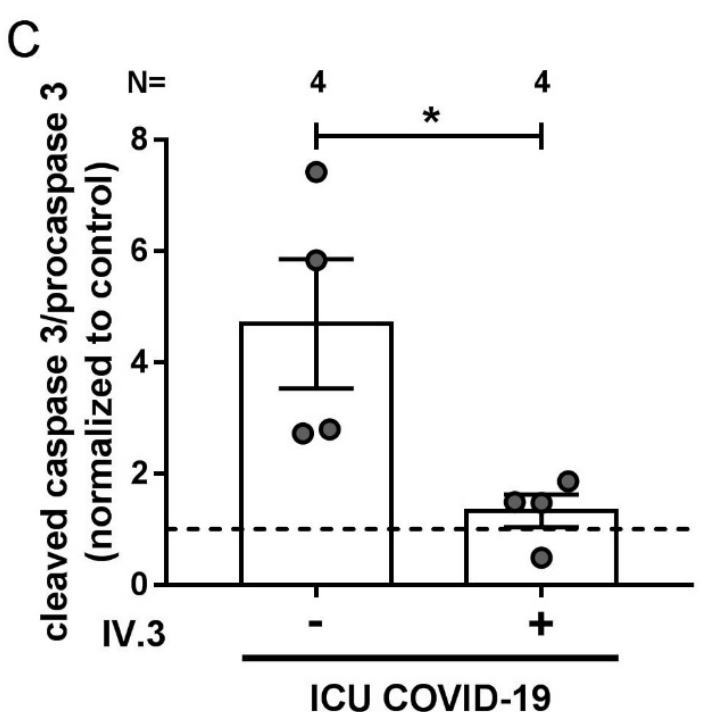


Figure 4.2.

ICU COVID-19

A B
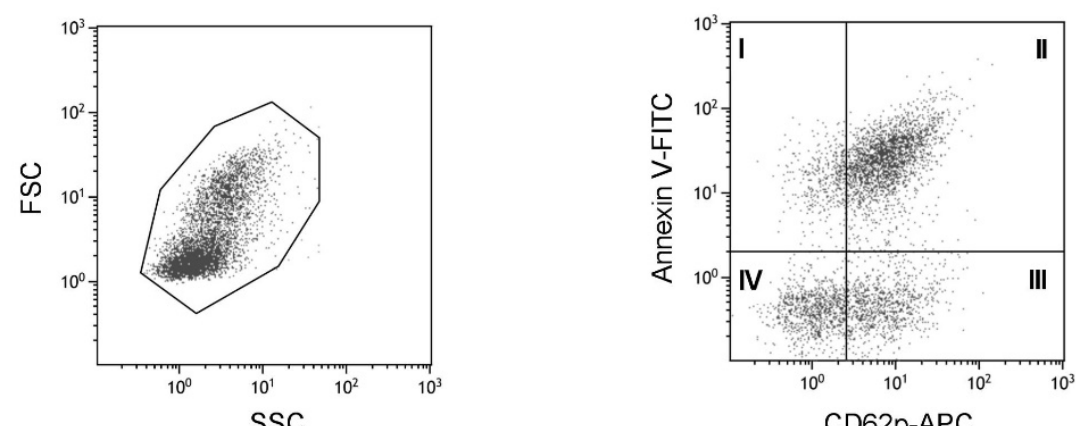

CD62p-APC

+isotype control

C

D
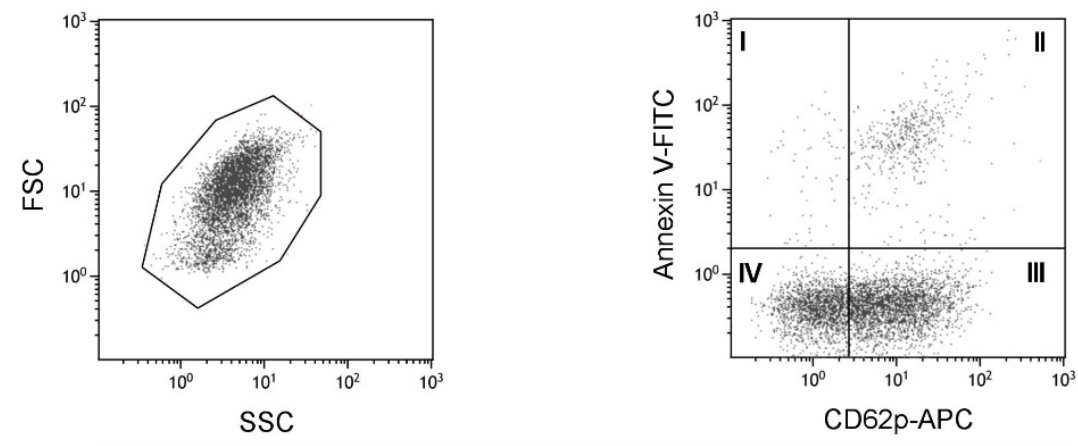

+IV.3
Figure 4.2. I-IV

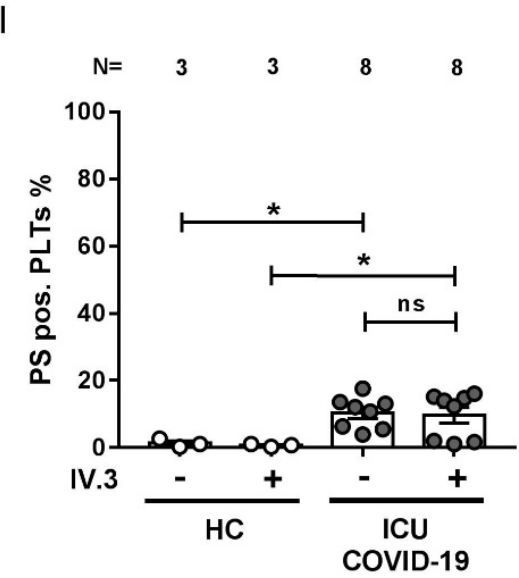

II

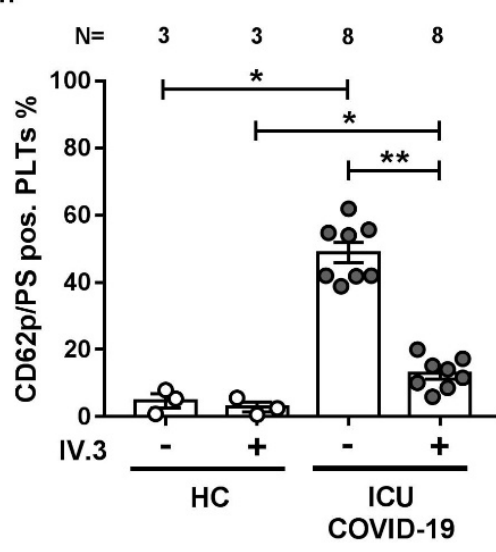

IV

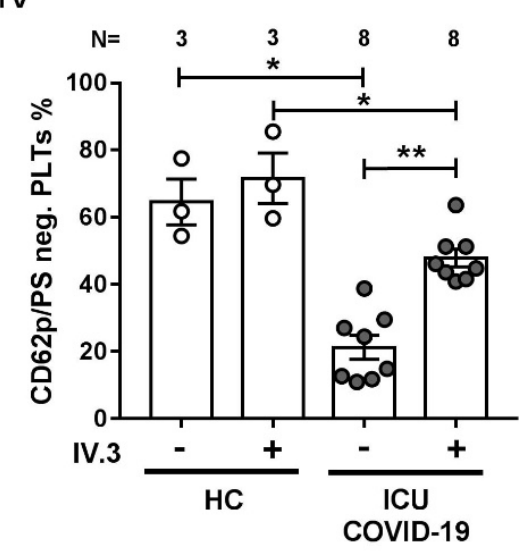

III

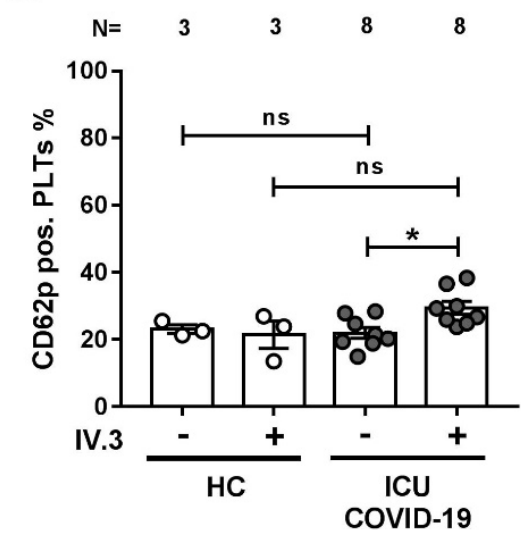


Figure 5

A
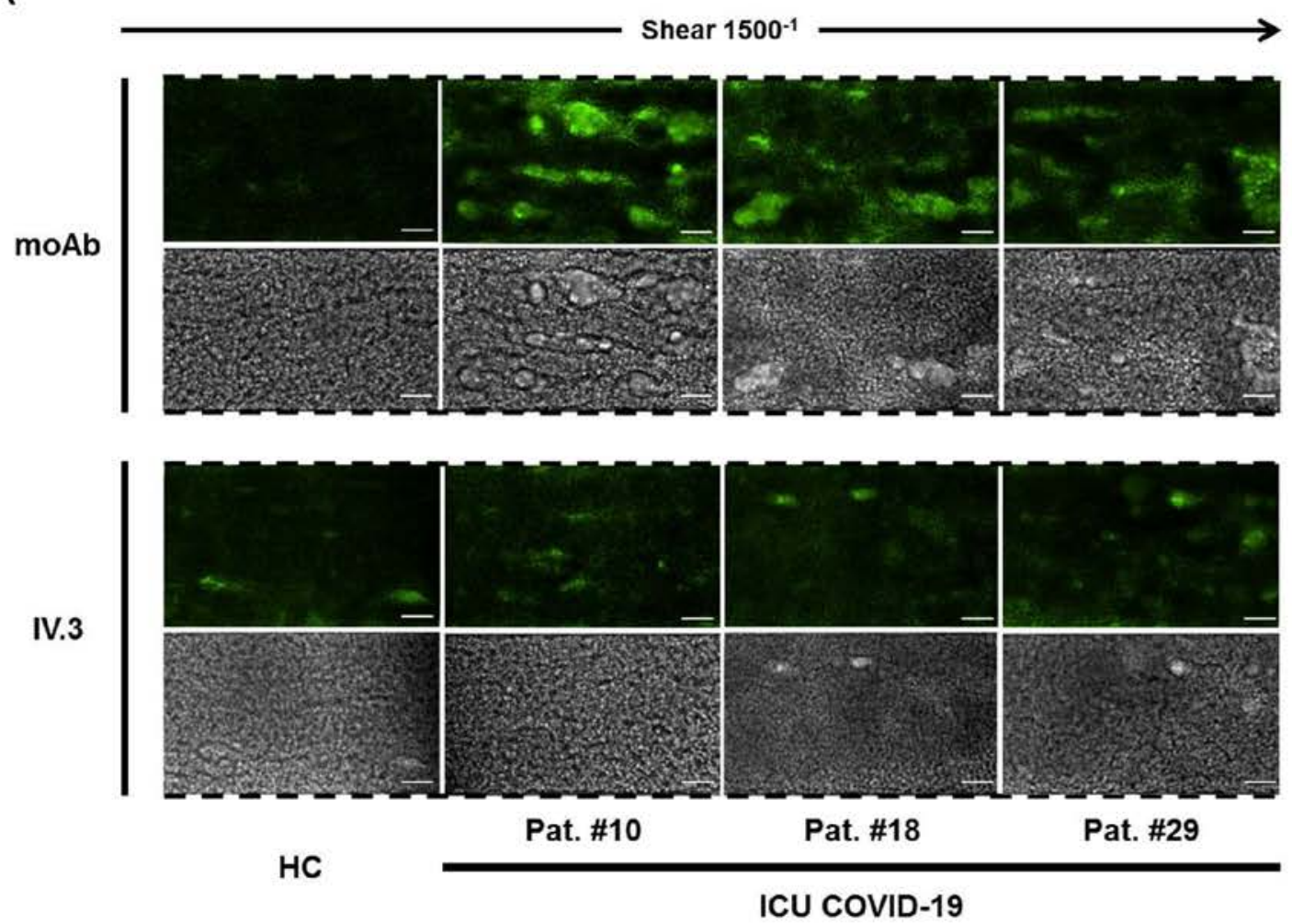

B

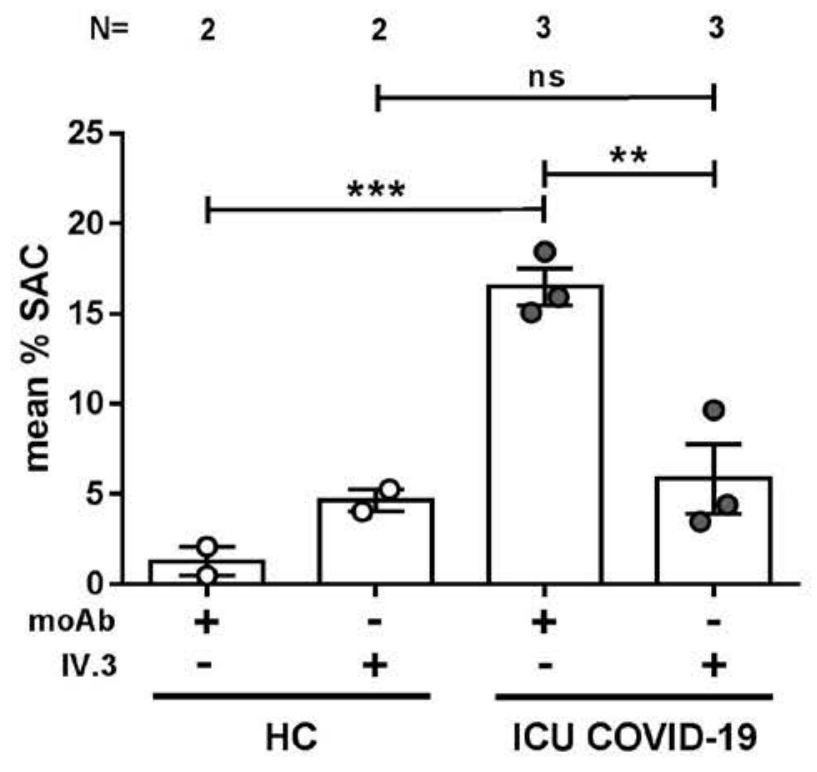


Figure 6.1.

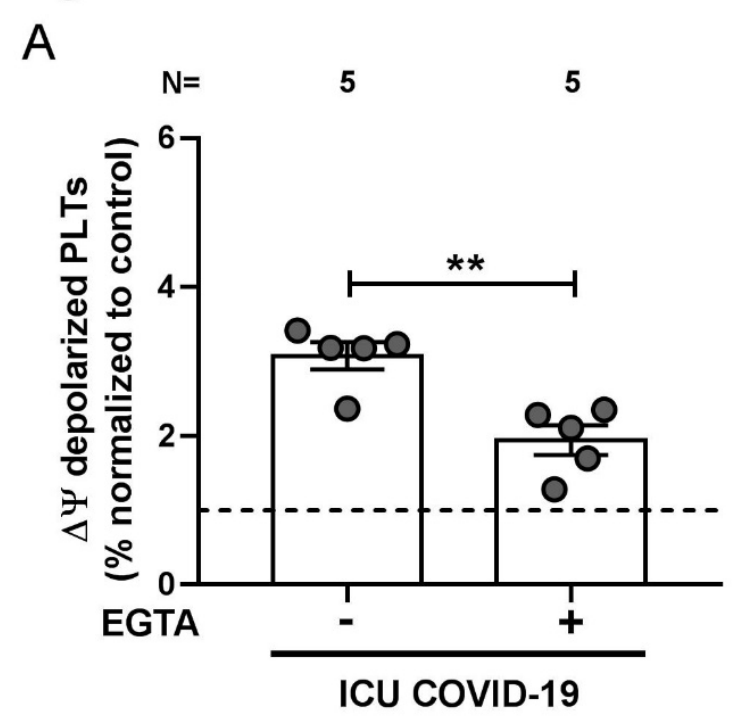

B

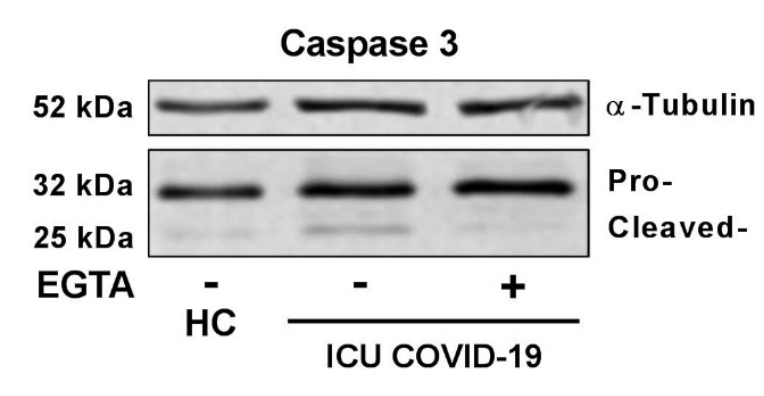

C

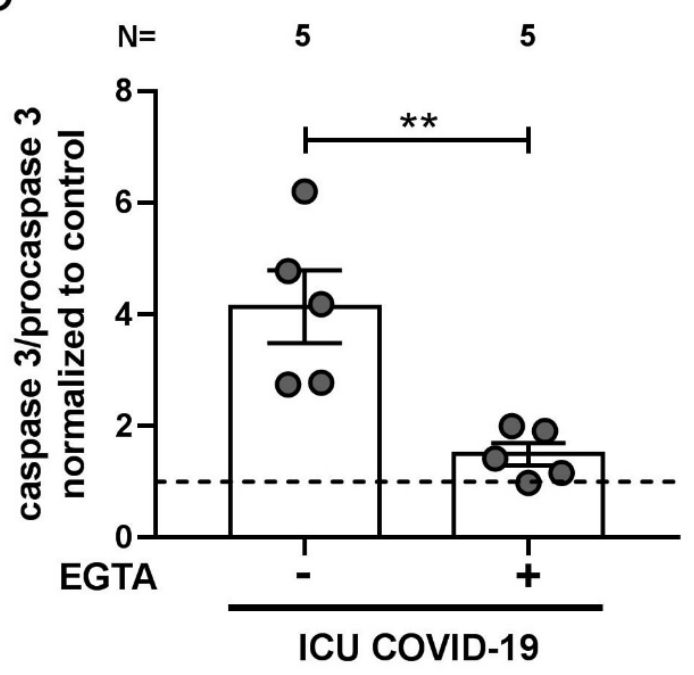


Figure 6.2 .

ICU COVID-19

A
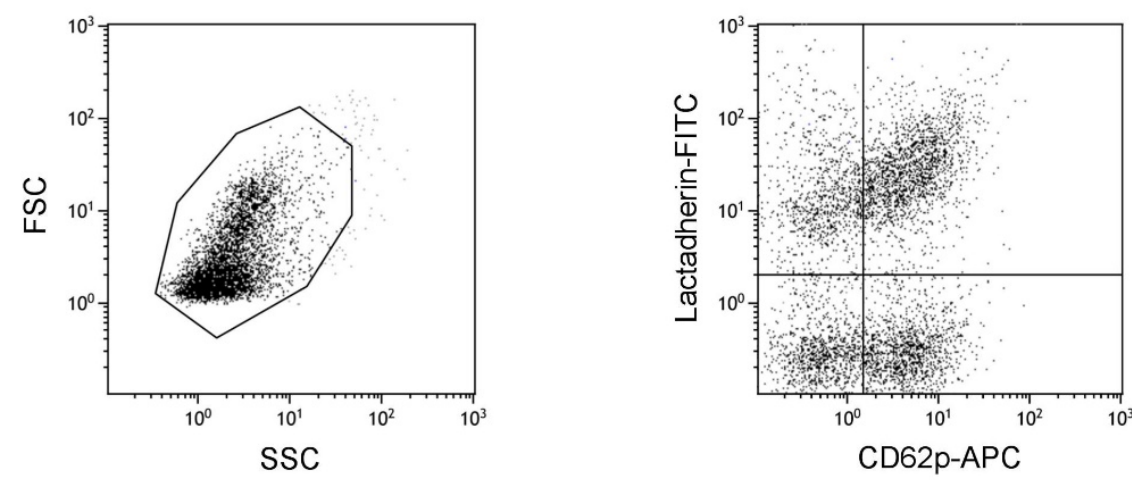

+Vehicle

C

D
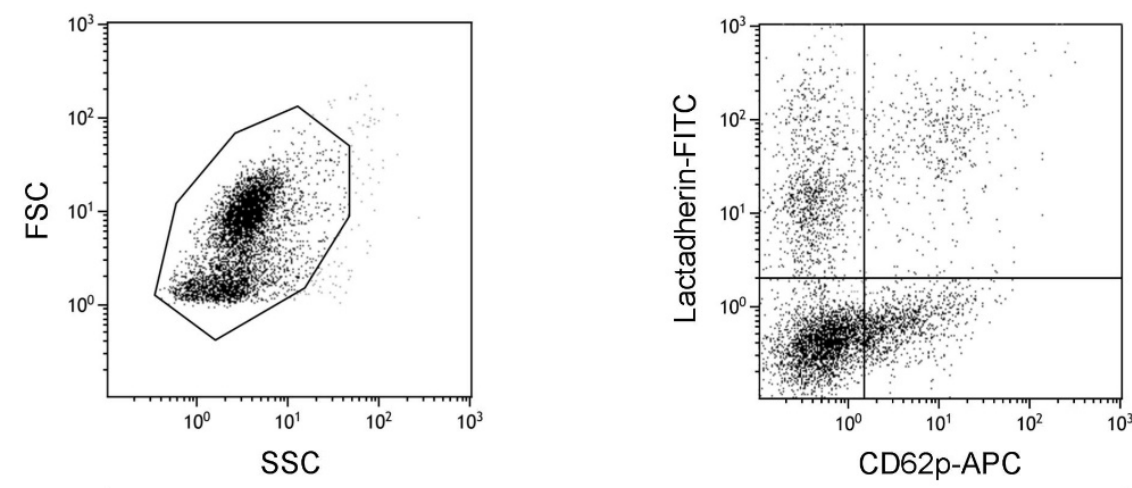

+EGTA
Figure 6.2. I-IV
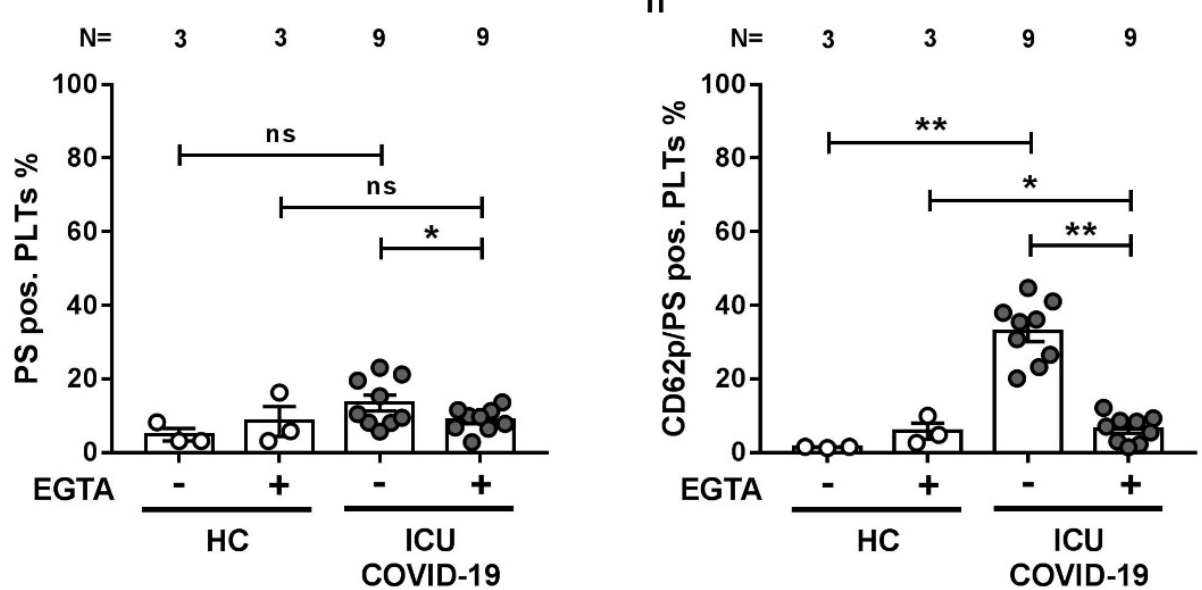

IV

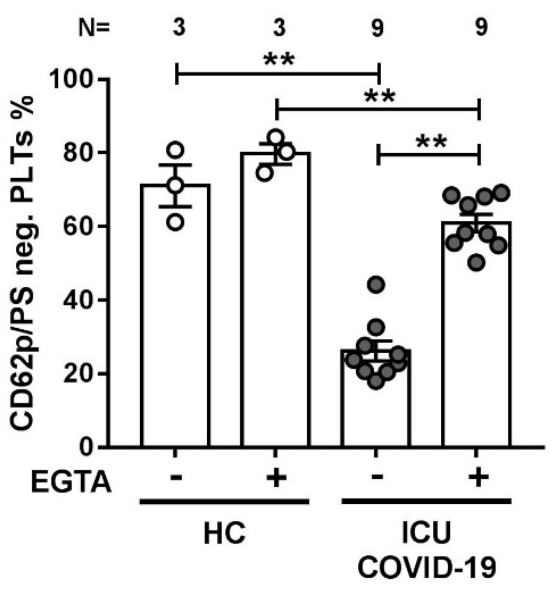

III

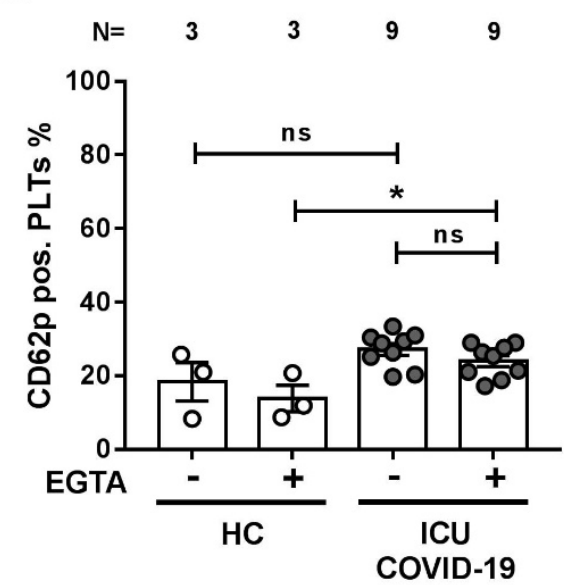


Figure 7.1.

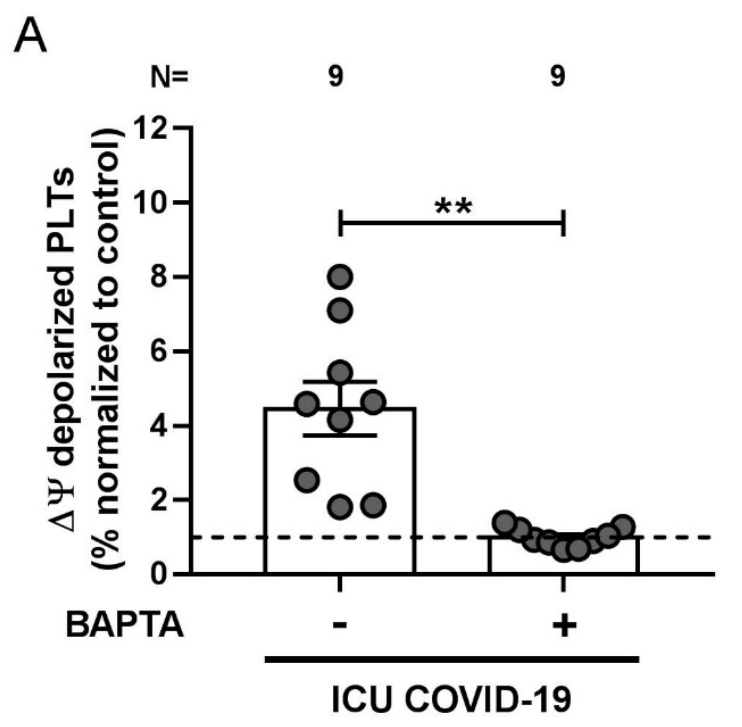

B

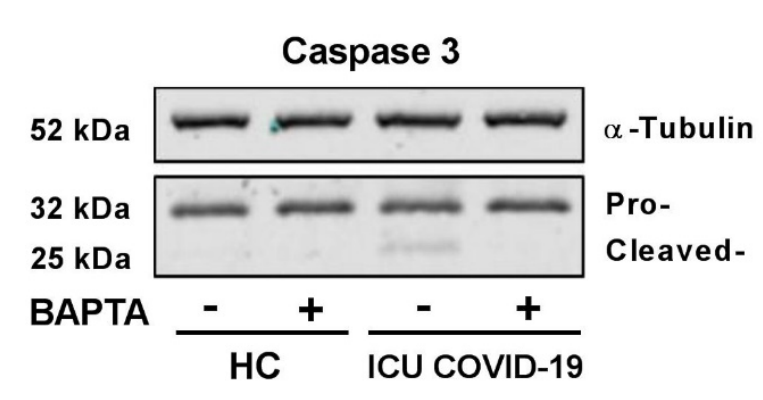

C

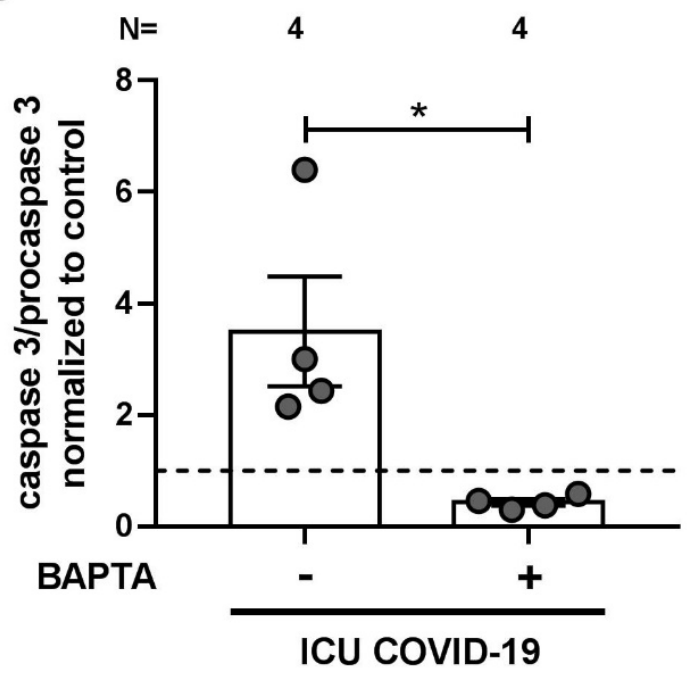


Figure 7.2.

ICU COVID-19

A
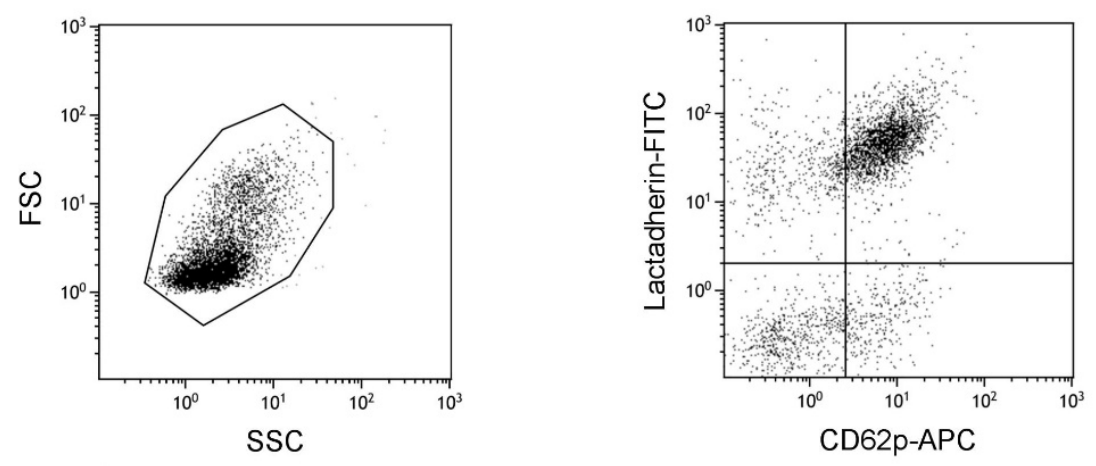

+Vehicle

C

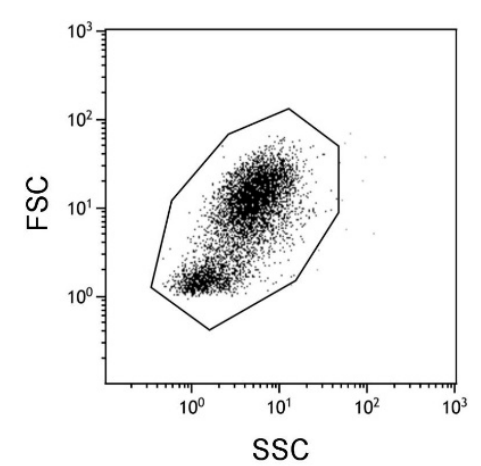

B

D

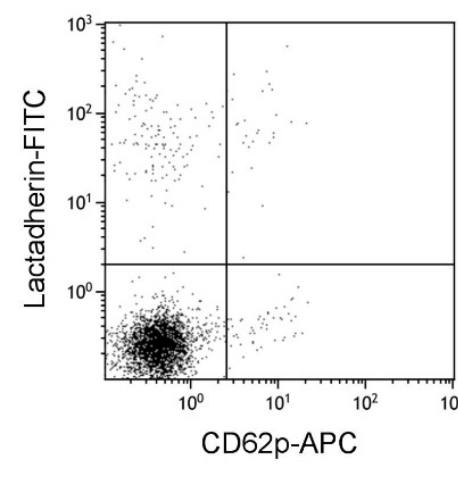

Figure 7.2. I-IV
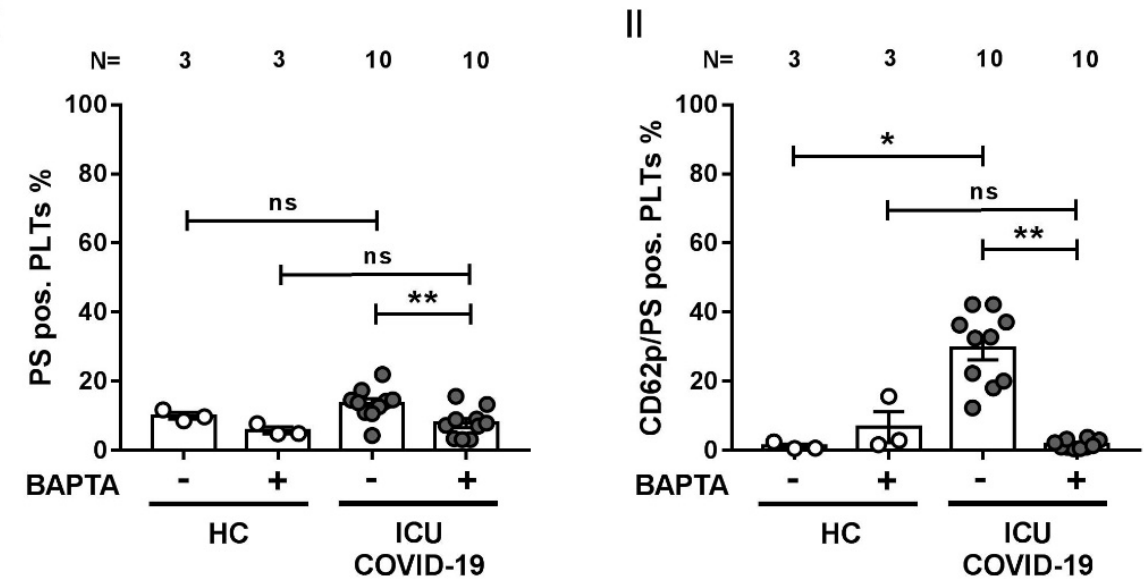

IV

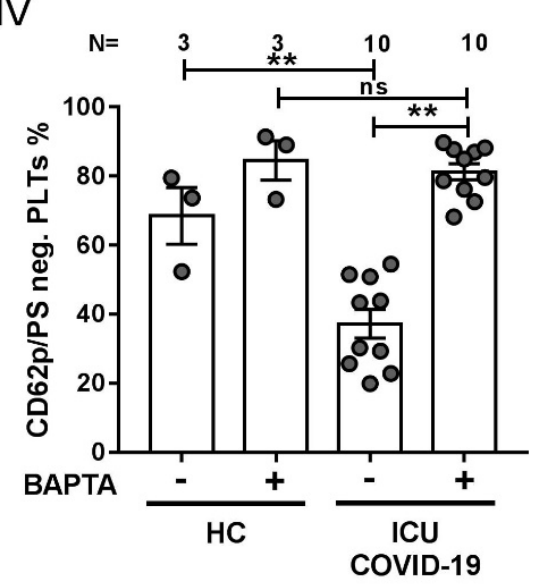

III
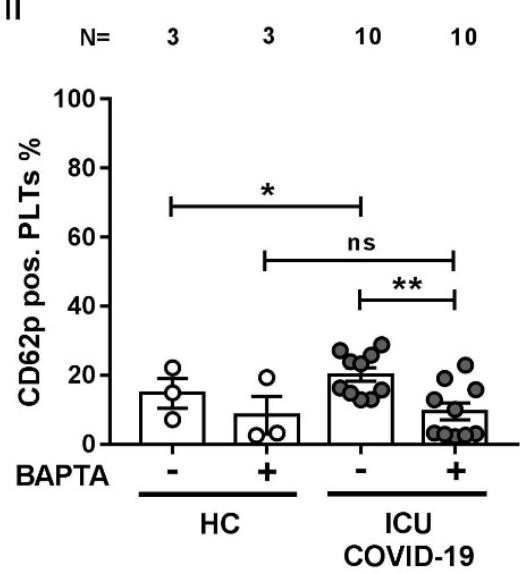

+BAPTA 
Figure 8.1.

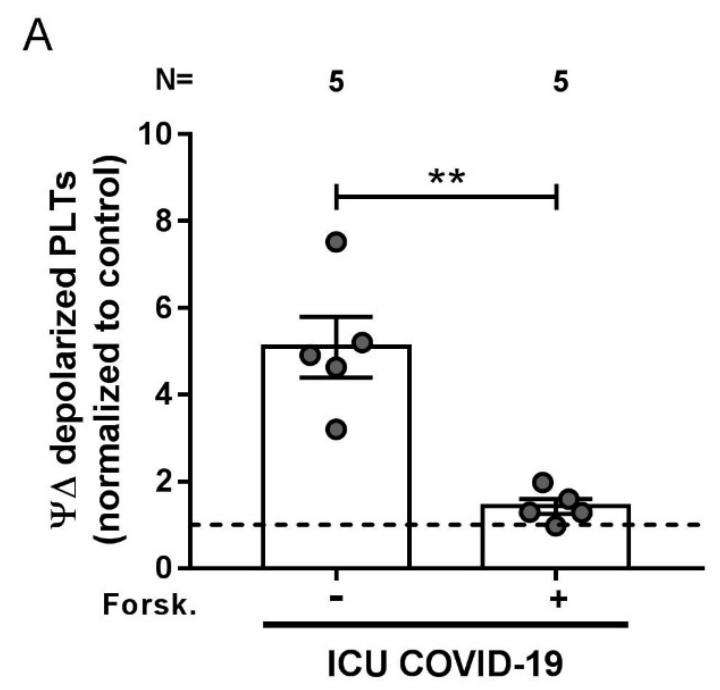

B

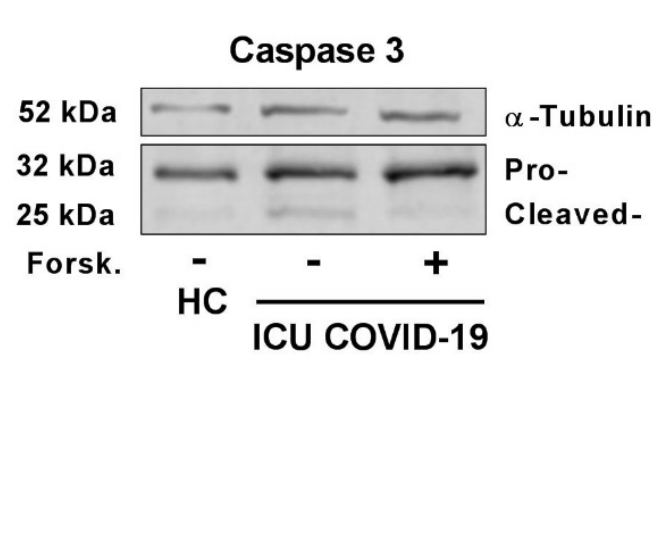

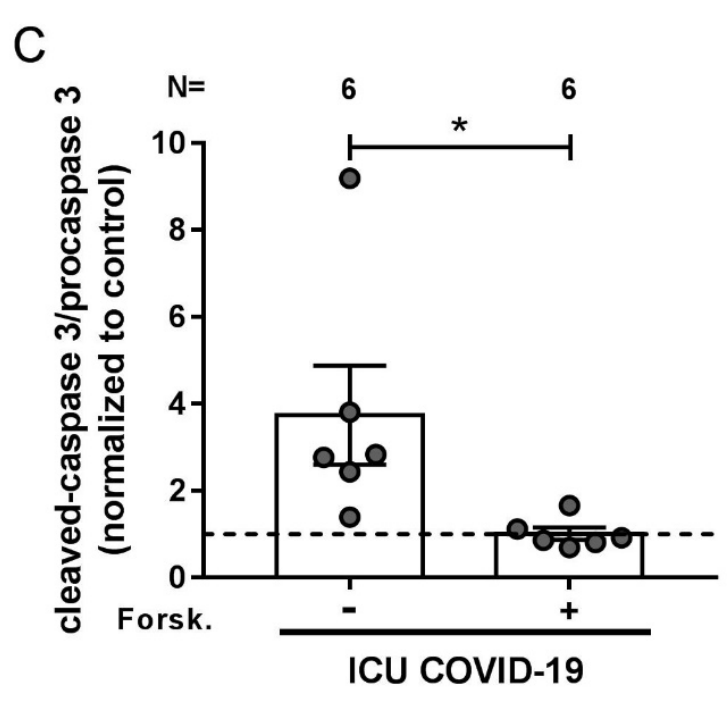


Figure 8.2.

ICU COVID-19

A

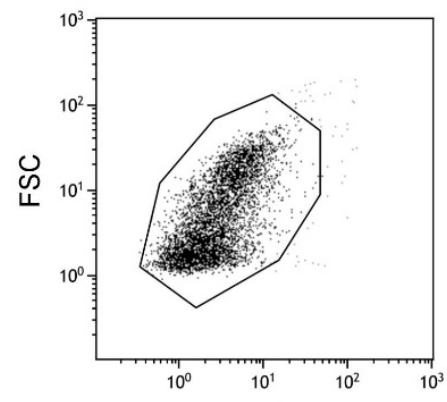

SSC
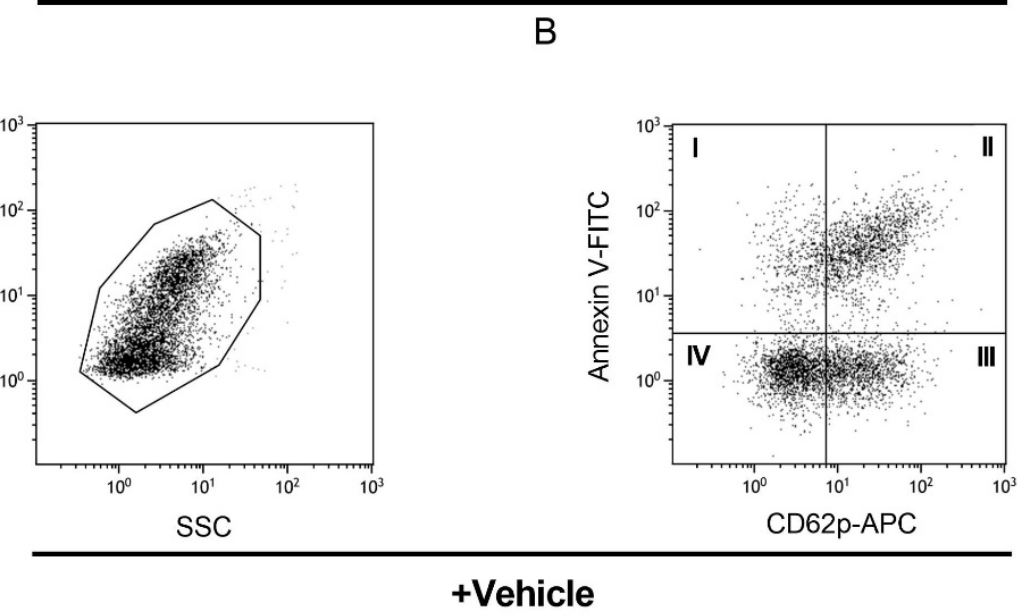

C

D

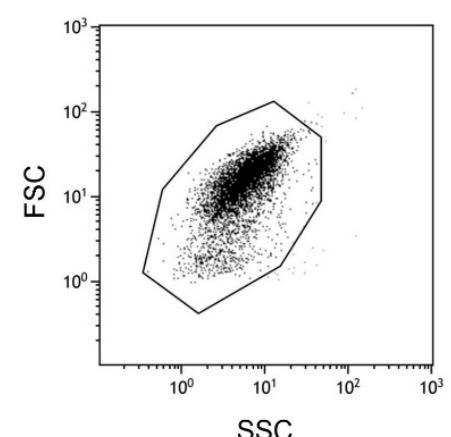

SSC

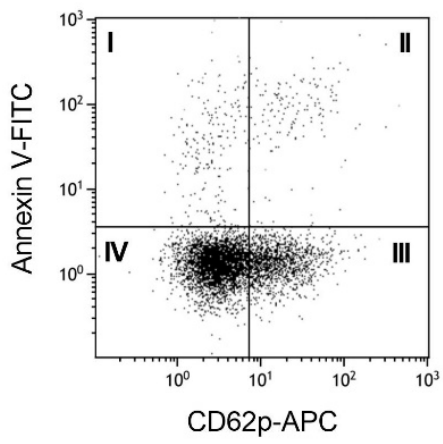

CD62p-APC
Figure 8.2. I-IV

I

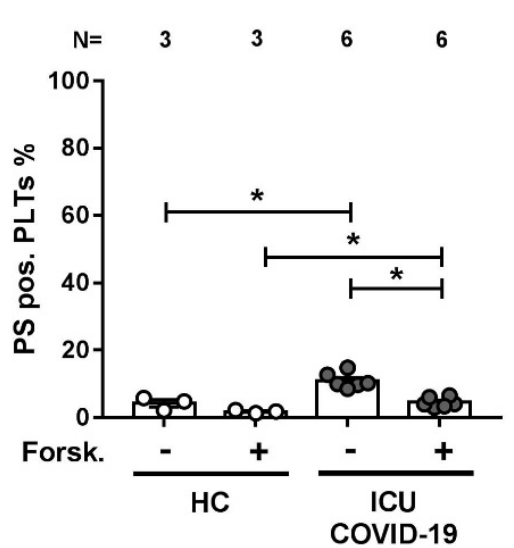

IV

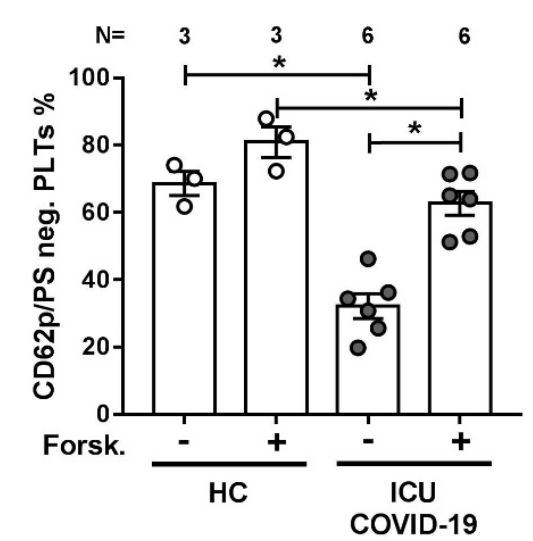

II

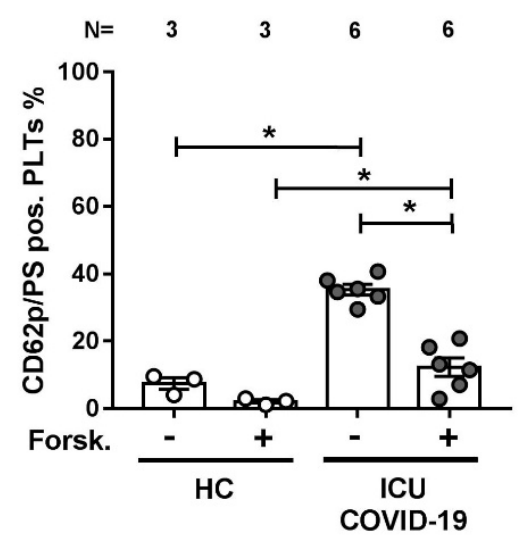

III

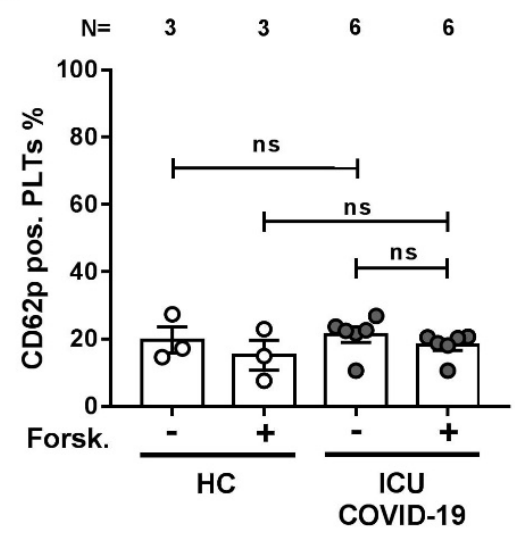$$
\text { COVID-19 }
$$ 
Figure 9.1.

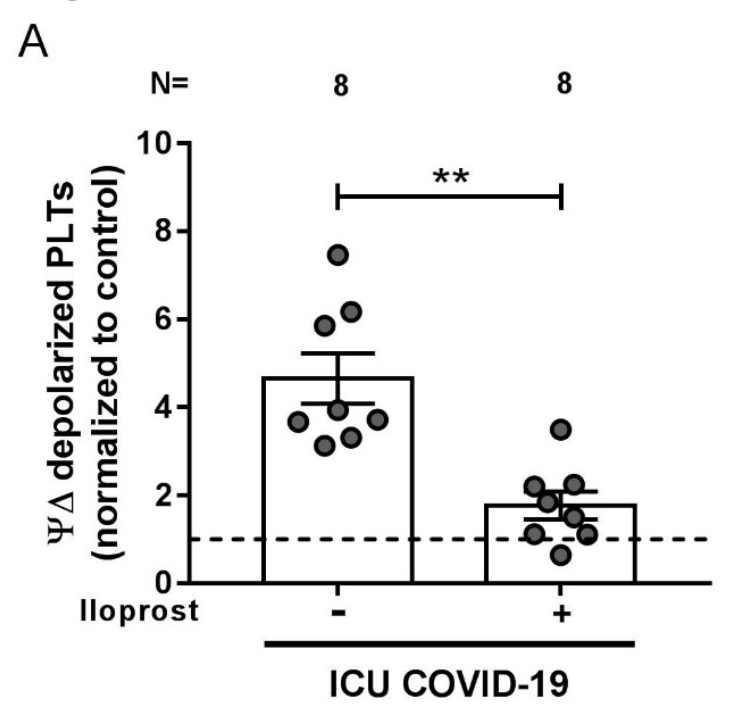

B

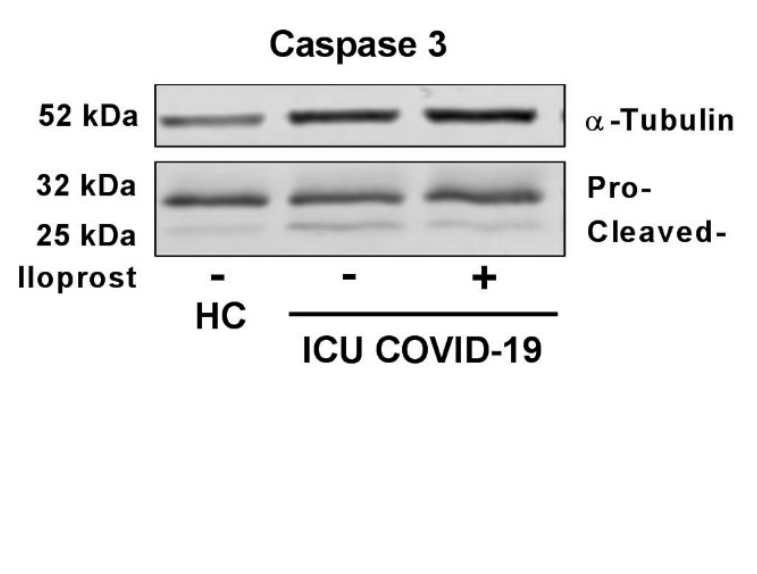

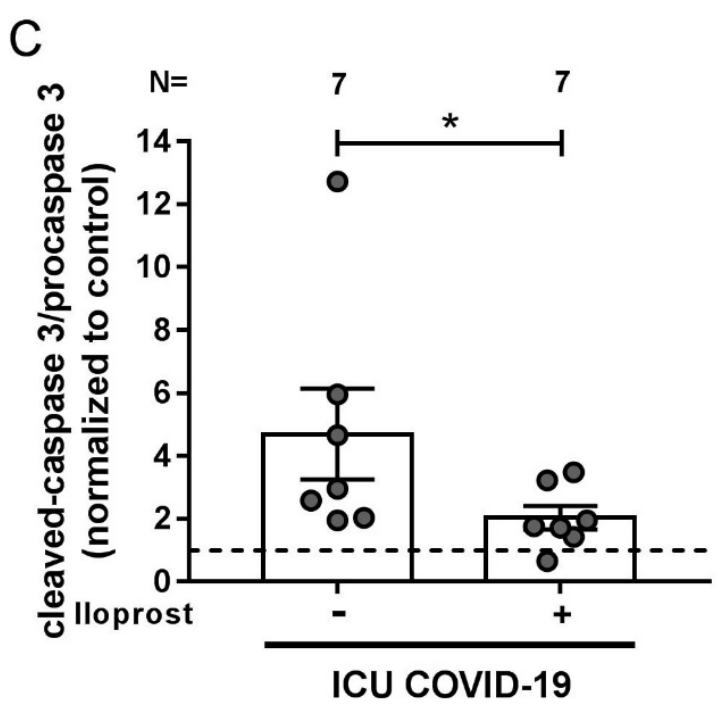


Figure 9.2.

ICU COVID-19

A

B
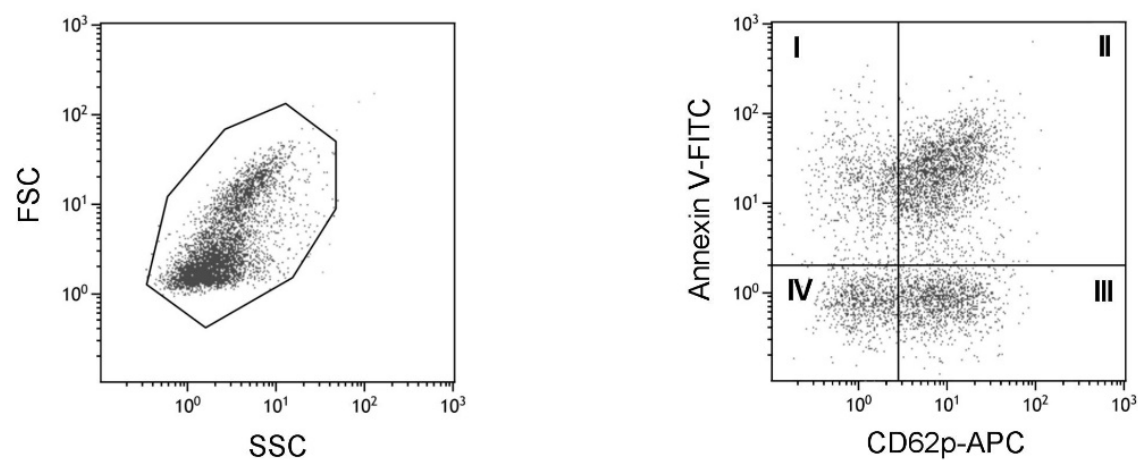

+Vehicle

C

D

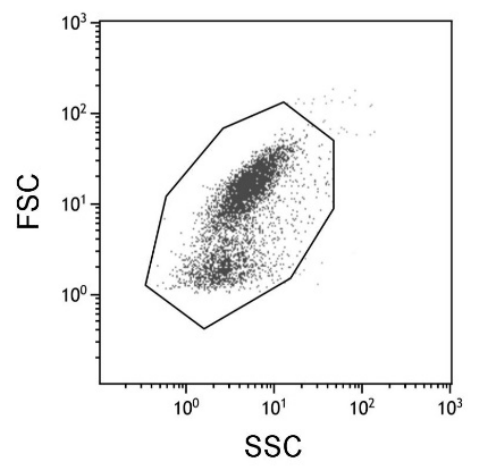

SSC

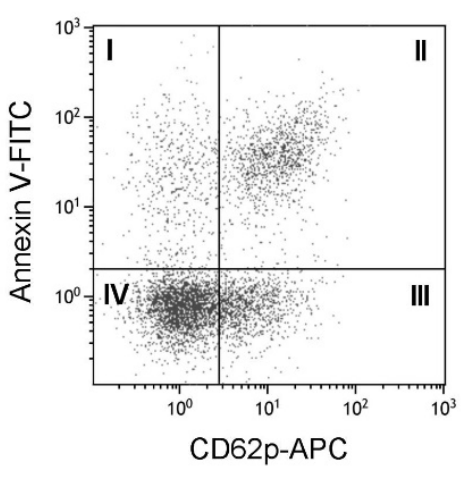

CD62p-APC
Figure 9.2. I-IV

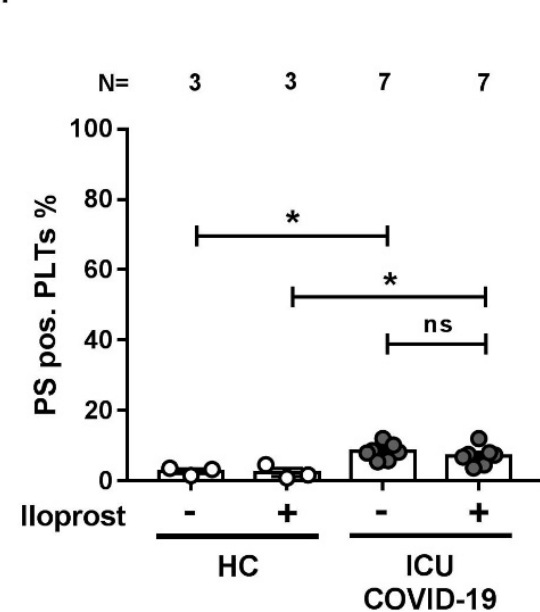

IV

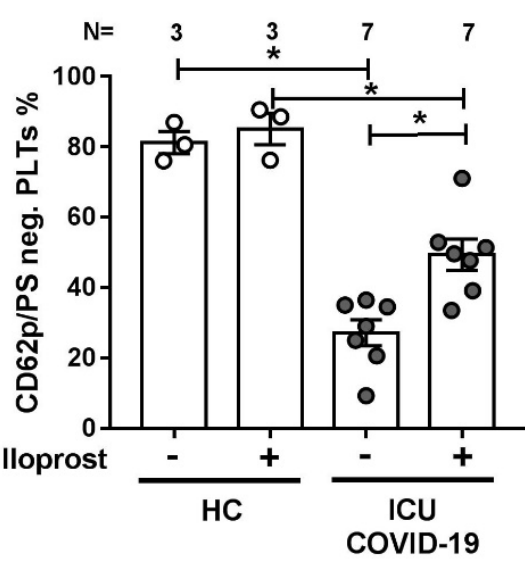$$
\text { OVD-19 }
$$

II

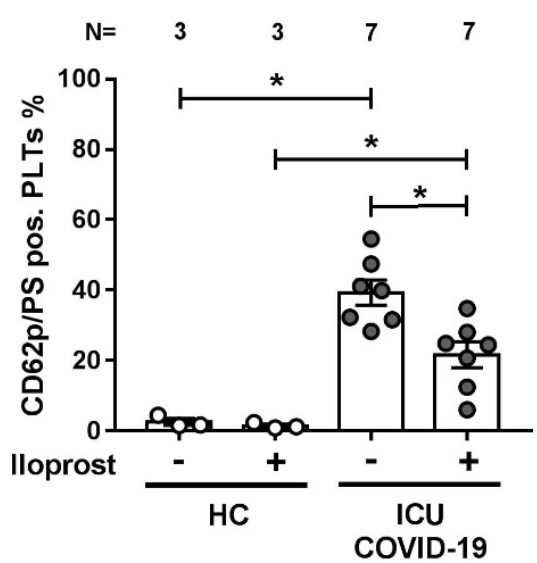

III

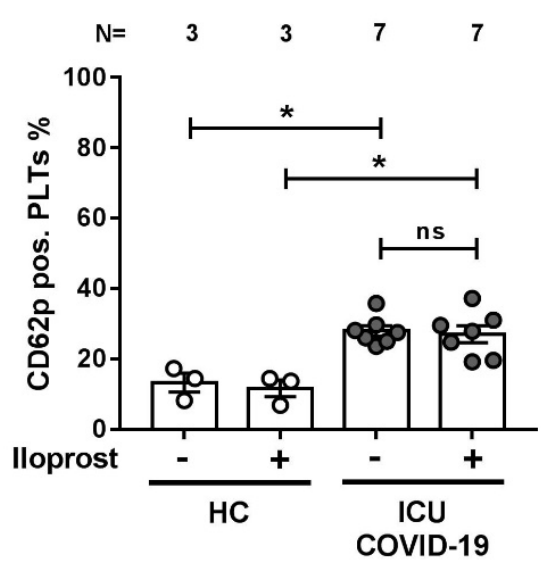


Figure 10

A
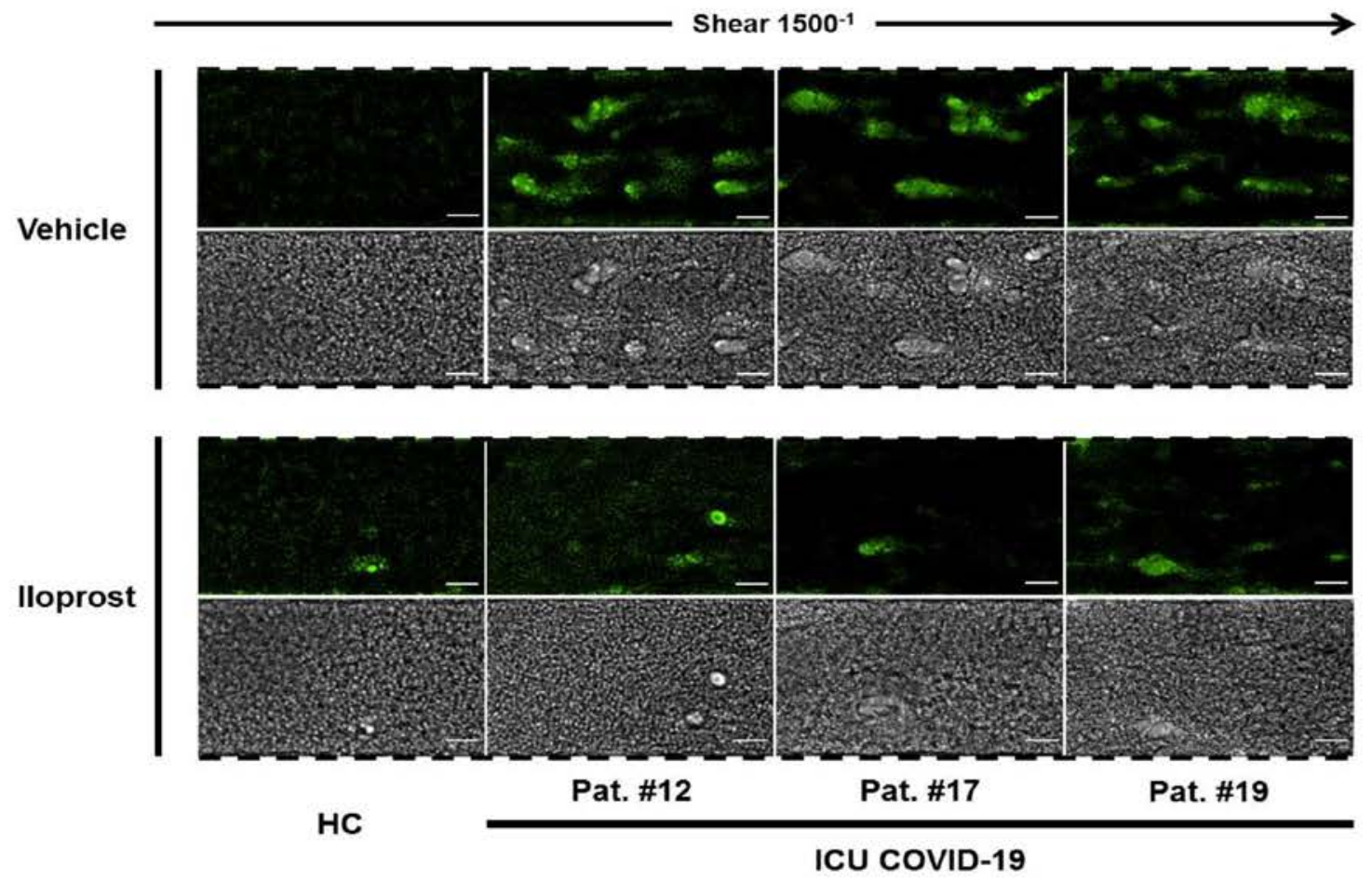

B

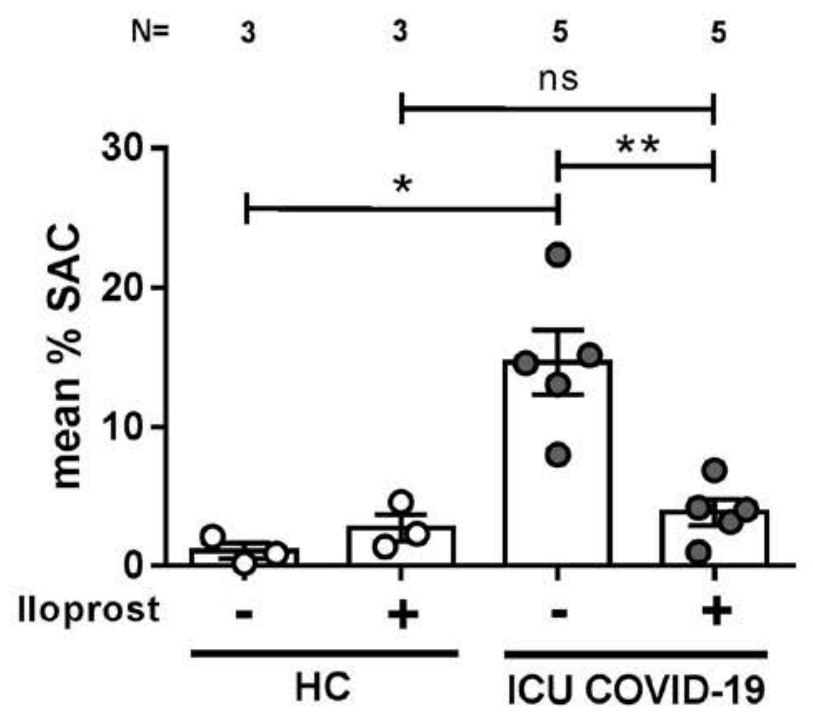

